\title{
Generativity, aging and subjective well-being
}

\author{
Leonardo Becchetti ${ }^{1}$ - Davide Bellucci ${ }^{2}$
}

Received: 7 March 2020 / Accepted: 12 September 2020 / Published online: 3 October 2020

(c) The Author(s) 2020

\begin{abstract}
We show that generativity, intended as the capacity of affecting positively other human lives, has a strong and significant effect on life sense and life satisfaction of individuals aged 50 and above. We define three generativity dimensions: individual generativity power, local generativity power and individual generativity in act. We find that generativity in act (both in its leisure and work dimensions) has a positive and significant effect on subjective well-being. The gross effect is, however, smaller than the net effect since generativity in act is negatively correlated with the internal locus of control (control over one's own life). Our findings have strong policy implications since generativity affects consumption and saving choices of utility maximizing economic agents and policymakers may create consensus by building generative societies.
\end{abstract}

Keywords Life satisfaction $\cdot$ Subjective well-being $\cdot$ Life sense $\cdot$ Generativity

JEL Classification A13 $\cdot$ B21 $\cdot$ D64 $\cdot$ I31

\section{Introduction}

Mill "Those only are happy, I thought, who have their minds fixed on some object other than their own happiness, on the happiness of others, on the improvement of mankind, even on some art or pursuit, followed not as a means, but as itself an ideal end. Aiming thus at something else, they find happiness by the way" (Mill, 1893: p.117)

The act of programming our (car or smartphone) satellite navigator to drive or walk toward a desired destination has become one of the most common actions in our lives. The most important decision when deliberating about such action is to

Leonardo Becchetti

becchetti@economia.uniroma2.it

1 University of Rome Tor Vergata, Rome, Italy

2 Collegio Carlo Alberto, University of Turin, Turin, Italy 
choose and write where to go. Once this choice has been made, the decision on "how to go" is taken by the satellite navigator that is programmed to minimize the time needed to reach the chosen destination.

In a similar way, in the more general issue of life direction, the crucial decision for rational and maximizing individuals consists of defining the destination that maximizes their own life sense and satisfaction as a goal for their life journey. After this decision is taken, rationality plays the role of the satellite navigator ensuring consistency between means and ends. This is why understanding drivers of life satisfaction is one of the most important topics in social and economic research if scholars and policymakers want to understand human action and choices.

Our paper aims to provide an original contribution to this important field of the literature by investigating an absolutely new and unexplored concept in economics (generativity) and testing its role as a driver of life satisfaction, with empirical findings that open the way to important considerations for social and economic policies.

The concept of generativity in social sciences originates from the seminal work of Erikson (1993 and 1998). According to the psychologist, human beings live eight stages of psychosocial development. ${ }^{1}$ Generativity is the positive response to the seventh stage concerning a crucial period of adult life going, according to Erikson, between 40 and $65 .^{2}$ This is a phase in which individuals continue to build their career and relational life and feel themselves "generative" when they believe to contribute positively with their work and activities to the life of their inner and outer circles (family and communities). In the same direction, Fisher (1995) contributes to this literature by considering generativity in older age as a fundamental factor concurring to successful aging. He notes that for elder people, the possibility of feeling useful to the growth and development of someone else represents an essential aspect to perceive life as meaningful during its later stages.

According to Erikson, generativity consists in the sequence of four verbs: to desire, to give birth, to accompany, to let it go. This means that it is originated by the desire/willingness to pursue some socially desirable goal and that it comes into act with the birth of an action/activity. Generativity can grow and prosper only if the action/activity is cultivated and if the "originator" has the intelligence to understand that the activity cannot survive if it remains only on his/her shoulder. In this sense, financial markets can be conceived as playing an important role for economic generativity by easing the creation of companies and the intra- and intergenerational transfer of their property, that is, financial markets help to "give birth," "accompany" and "let it go" corporate organizations that create economic value.

Using a language closer to that of the economics and welfare literature, we can define generativity at individual level as the act of an individual using his/her

\footnotetext{
${ }^{1}$ More specifically, Erikson's model of psychosocial development includes the following eight stages and challenges (Stage 1-Trust vs. Mistrust Stage 2-Autonomy vs. Shame and Doubt Stage 3-Initiative vs. Guilt Stage 4-Industry vs. Inferiority Stage 5-Identity vs. Confusion Stage 6-Intimacy vs. Isolation Stage 7-Generativity vs. Stagnation Stage 8-Integrity vs. Despair).

2 According to Erikson (1993), individuals focus on career and family during their adulthood. When they feel they are contributing by being active at home and in the society they consider themselves successful. Those who do not feel involved view themselves as unproductive and experience a sense of failure.
} 
available set of doing and being (capabilities) and the states of being and doing (functionalities) for doing things that he/she expects may have positive effects on the life of other human beings ${ }^{3}$ and, through them, also indirectly on his/her own life. As such, capabilities and functionings are necessary but not sufficient conditions for generativity (as they affect generativity power but they may not become generativity in act).

In a sense, the above definition of generativity operationalizes a well-known say of Genovesi ${ }^{4}$ and John Stuart Mill (see our quote at the beginning of the paper) on happiness conceived as the unintended effect of a life dedicated to an activity that can contribute to the improvement of the mankind or of at least one other human being. The positive effect on one's own life and on life of other human beings implied by generativity includes valuable social and economic initiatives, altruistic actions but also relational life.

The concept of generativity aims to provide an original contribution to the ample literature of the determinants of subjective well-being. As we know a starting point of this literature is the Easterlin paradox with its descriptive evidence on the decoupling between per capita GDP and the share of very happy individuals in the US after the Second World War. The paradox illustrates the fact that GDP is not a synthetic measure capturing sufficiently well neither subjective well-being nor even economic satisfaction of the individual, which is better measured by household disposable income net of the cost of crucial goods such as education and health. ${ }^{5}$ Stimulated by the always wider availability of data on life satisfaction and life sense, the empirical literature on their drivers has evolved in several directions (for a survey on the life satisfaction literature see, among others, Veenhoven 1993; Frey and Stutzer 2002; Blanchflower and Oswald 2004; Clark et al. 2006; Becchetti and Pelloni

\footnotetext{
3 As is well known, the concepts of capabilities and functionings have been first developed by Sen (1985) and Nussbaum (1988). According to Sen, functionings are "states of being and doing" that relate to individual well-being (i.e., being educated, healthy) and, as such, they are not identified in the goods that can be used as means to enable them. Capabilities are instead the set of functionings that an individual has access to. In this respect, while generativity in power relates to those capabilities and functionings that make generativity acts possible, generativity in act implies the use of capabilities and functionings for actions that are generative, i.e., that are likely to affect positively lives of other human beings.

4 "Fatigate per il vostro interesse, niuno uomo potrebbe operare altrimenti, che per la sua felicità sarebbe un uomo meno uomo: ma non vogliate fare l'altrui miseria, e se potete e quando potete studiatevi di far gli altri felici. Quanto più si opera per interesse, tanto più, purchè non si sia pazzi, si debb'esser virtuosi. È legge dell'universo che non si può far la nostra felicità senza far quella degli altri" [work hard for your own interest, no man could do otherwise, as he would be less human by not doing so: but do not work for the misery of others and, if possible, work out how to make them happy. The more you are self-interested, the more you must be virtuous if you are not fool. Is a natural law that you cannot make your own happiness without making that of other human beings] (Genovesi, Autobiografia e lettere, p. 449).

5 After the Easterlin's contribution, many other authors have verified the regularity of this empirical evidence in different countries and periods. Support for the paradox has been found by Blanchflower and Oswald (2004) in the United States, United Kingdom, Belgium and Japan between 1970 and 1990, by Veenhoven (1993) in Japan between 1958 and 1987 and by Frey and Stutzer (2002) in the World Database of Happiness and the US Bureau of Census. Stevenson and Wolfers (2008) find evidence against the paradox. Easterlin and Angelescu (2009) reply arguing that the paradox concerns the long-term relationship between per capita GDP and happiness at cross-country level.
} 
2013). The usefulness of subjective well-being in the economic literature has grown in parallel with evidence on its effects as predictor of relevant economic variables such as job quit and productivity (Judge 1992; Staw and Barsade 1993; Judge et al. 2001), self-assessed health and mortality (Becchetti et al. 2019; Idler and Kasl 1995; McCallum et al. 1994; Benjamins et al. 2004; Idler and Angel 1990 and Appels et al. 1996) and insurgence of chronical illnesses (Becchetti et al. 2019), to its usefulness to calculate the value of nonmarket goods with the compensating variation approach (Welsch 2002 and Luechinger 2009; Luechinger and Raschky 2009; van Praag and Baarsma 2005; Frey et al. 2009) and its importance for measuring satisfaction of citizens and voters for policymakers.

The life satisfaction literature has created a closer integration among social sciences (investigating the role of peer comparisons from sociology ${ }^{6}$ and hedonic adaptation from psychology for instance) and has helped to go beyond the "consequentialist" utilitarian approach by which satisfaction is univocally defined by the outcome and not by circumstances lived during the action that led to the outcome itself. $^{7}$

A line of conflict in the subjective well-being literature has been that between life satisfaction and the Amartya Sen's capability approach. While life satisfaction has the unique advantage of being not "paternalistic" (since no one else than the individual involved may evaluate his/her own life satisfaction), it also suffers from the "happy slave" Sen's (1985) critique, ${ }^{8}$ by which even the most deprived can paradoxically declare themselves satisfied with their life if the level of their expectations is so low to eliminate any hope for improvement.

The generativity approach proposed in this paper lies somewhat in the middle. It looks at the life satisfaction and life sense effects of the generativity concept to test whether the latter concretely satisfies self-declared subjective well-being. In this sense, it proposes an extension of the capability approach where generativity occurs only if the available set of doing and functionings (driven by good health, economic well-being, education) is effectively geared toward an activity through which individuals contribute positively to subjective well-being of other individuals. In a nutshell, if the capability approach concerns mainly (even though not exclusively) freedom and potential (akin to the Aristotelean concept of "power"), the generativity approach concerns the freedom and potential that is put into specific actions (akin to the Aristotelean concept of "act") to pursue activities that can positively contribute to well-being and self-fulfillment of other human beings.

The literature on generativity has found developments in the last decades especially in social psychology where a generativity index has been elaborated (the

\footnotetext{
6 See among others (Ferrer-i-Carbonell 2005), Dorn et al. 2008; Clark 2008; Clark and Senik 2010).

7 Frey and Stutzer (2005) with their work on procedural utility provide an important example of it when showing that the same outcome may be appreciated or not, depending on whether those evaluating it have been involved or not in the process of its creation.

8 "The defeated and the downtrodden come to lack the courage to desire things that others more favourably treated by society desire with easy confidence" (Sen 1985: 15).
} 
Loyola Generativity Scale) and its impact tested with a Generativity Behavioral Checklist (GBC) (McAdams and St. Aubin 1992 and 1998; Aubin et al. 2004).

Shahen et al. (2019) test the effect of generativity on subjective well-being using the GBC. Other contributions investigate the nexus between generativity and the environment (Jia et al. 2015 and 2016, Matsuba et al. 2012), while others the role of altruism as mediator in the link between generativity and life satisfaction (Hofer et al. 2016).

Our paper, by testing the effect of generativity on subjective well-being, aims to provide an original contribution to this literature in several respects.

First, we do not use an ad hoc created survey but test the effect of generativity on an international survey (Survey of Health, Ageing and Retirement in Europe SHARE) representative at country level. The advantage is that of testing our research hypothesis on larger numbers and a wider set of countries at the same time. We as well decompose generativity into three parts and introduce two new "generativity in power" indicators, while our "generativity in act" indicator is what is closest to LGS and GBC based on the SHARE database.

As well, the test for the existence of a gross effect and a net effect after controlling for the concurring loss of locus of control is a novelty of our approach. In this respect, we highlight a trade-off in the generativity-well-being relationship based on the negative relationship between generativity and locus of control.

The characteristics of the SHARE database are such that our analysis is concentrated on people aged 50 and above. This is a limit but is also related to the original concept of Erikson considering generativity the stage for evolution in an adult phase of life. We hope that our work will stimulate further research to test whether similar findings occur when looking at younger generations

As a measure of generativity, we use an index of activities that unambiguously produce positive effects on the lives of other human beings. Since these activities are mostly correlated with our leisure time, they do not fully capture the generativity/nongenerativity component correlated with professional life. In order to overcome this limit, we use the job taxonomy of the SHARE database to define professions that are more/less generative. We therefore end up with two variables measuring generativity mostly in leisure and in working time, respectively.

Our findings show that the first (leisure) generativity measure contributes positively and significantly to life satisfaction and more so to life meaning. We as well find that generativity is more precious (has a higher marginal utility) for those individuals with lower individual generativity power (i.e., with living conditions that make generativity more difficult such as older respondents, respondents with lower income and health). Our hypothesis on the job generativity measure is as well not rejected since jobs with higher generativity potential contribute more significantly to life satisfaction and life sense. We also find that the gross effect of generativity in act on subjective well-being is smaller than the net effect. This is because generativity in act is correlated with lower control over one's own life that, in turn, negatively affects life satisfaction. Our findings therefore identify a trade-off where "freedom for" (individual generativity in act) reduces "freedom of," but nonetheless positively contributes to life satisfaction and life sense. 


\section{The three components of generativity and our research hypotheses}

We conceive generativity as having three dimensions. The first is generativity potential at individual level. To be generative, individuals need good health and sufficient economic resources. Education is a third crucial factor that enhances individual potential for generativity.

The second dimension is generativity potential at local level and relates to the political environment in which the individual lives. Freedom of initiative, lack of corruption, equal opportunities, access to sources of external finance are all political conditions that make generativity possible.

The third dimension is generativity in act that goes from biological generativity (having children), to social, political and economic generativity as it involves all individual actions that may have a positive effect on lives of other human beings. As such, generativity in act concerns not only leisure activities, such as voluntary work or participation in social or political groups, but also working activities. In this respect, we may reason on the different levels of generativity of different professions and test our hypotheses (as we will do in our empirical analysis that follows).

Based on these concepts, we formulate the following research hypotheses:

$\mathbf{H}_{01}$ Life sense and life satisfaction are positively correlated with the three generativity dimensions: individual generativity potential, local generativity potential and generativity in act

With this hypothesis, we mean that generativity affects positively and significantly life satisfaction and life sense in its different dimensions beyond the traditional controls used in this literature. More specifically, based on what is considered above, we identify three components (individual generativity power, local generativity power and individual generativity in act) and split the latter into leisure and work (generativity in act) components. We argue that the two (individual and local) generativity power dimensions have a significant effect per se for two reasons. First, the two dimensions of (individual and local) generativity power are enjoyed per se and in the perspective of their future expected use. Second, generativity power (under the assumption that it is enacted) proxies part of the unobservable generativity in act given the inevitable limits of identifiable proxies to measure generativity in act itself. A problem when testing this hypothesis is that individual generativity potential coincides with standard controls in subjective well-being estimates. Hence, what is more interesting is to test the role of individual generativity in act.

$\mathbf{H}_{02}$ Individual generativity in act is more related to life sense than to life satisfaction.

As shown by Nikolaev (2018), education (one of the factors affecting generativity) enhances capabilities and functionalities and therefore the individual's generativity power. In this respect, it raises life sense. However, education may also raise expectations and reduce time left for leisure (thereby reducing individual control 
over one's own life). These two elements may have a negative effect on life satisfaction while not on life sense. To sum up, life sense is enhanced by more education but I may fell unsatisfied because my expectations are higher and I would like to have more time to express my generativity.

In the same way, very high expectations may prompt individuals to be highly generative and, at the same time, enhance the gap between their action and the goals they want to reach. As a consequence, individual generativity in act will definitely contribute in a strong way to life sense, while less so to life satisfaction.

$\mathbf{H}_{03}$ The marginal utility of generativity is higher/lower for individuals endowed with less generativity potential

The impact of generativity on life sense and satisfaction should be in principle the same for individuals with higher (lower) income and education (that is, generativity potential). We may on the contrary believe that individuals with lower generativity potential enjoy more generativity in act because they realize that their achievement is more difficult and precious, exactly as an "underdog win" produces higher satisfaction to its supporters.

$\mathbf{H}_{04}$ The gross effect of individual generativity in act is higher than the net effect

Generativity in act implies using one's own energies into a given direction. It requires effort and cultivation (i.e., raising children, engaging in social and political action, etc.). As such, it implies a trade-off between "freedom for" and "freedom of," thereby reducing individual control over one's own life (internal locus of control). Provided that the reduction of "freedom of" negatively affects subjective well-being, we assume that the effect of individual generativity in act on subjective well-being is stronger when we control for "freedom of" than when we do not.

\section{Source of data and main variables of interest}

The dataset used to perform our empirical analysis has been created by combining four data sources. The first is the "Survey of Health, Ageing and Retirement in Europe (SHARE)." 9 This survey-apart from baseline sociodemographic information, such as economic and marital status, years of education or health conditions-gathers, by means of specific modules, information on daily activities, social and family networks and subjective well-being, of more than 65,000 respondents aged 50 and over living in one of 20 European countries where SHARE survey is

\footnotetext{
9 The SHARE (Survey on Health, Ageing and Retirement) project is the most important EU longitudinal cross-national survey on individuals aged 50 or older at European level. It contains data on health, social networks and socioeconomic status for around 130 thousand individuals. National designs for data collection are made coherent and consistent by rigorous methodologies. More details on the project characteristics and on the wide literature using SHARE data may be found on the SHARE website.
} 
taken (Austria, Germany, Sweden, Netherlands, Spain, Italy, France, Denmark, Greece, Switzerland, Belgium, Czech Republic, Poland, Ireland, Hungary, Portugal, Slovenia, Estonia and Luxembourg). This database is particularly useful to test the Erikson's hypothesis of generativity that concerns mostly adult age. We specifically use to this purpose wave 5 that took place in 2013.

Our two main variables of interest are two measures of subjective well-being, eudaimonic happiness and life satisfaction. Self-assessed respondents' level of eudaimonic happiness is represented by the answer given to the question "How often do you think your life has meaning?". The four available options ("often, sometimes, never, rarely") and the specific wording of the question present at least two main advantages. First, the fact of anchoring numbers to specific evaluations, mirrored in the adverbs used as options, lowers the noise of more subjective interpretations that might emerge in scale measured questions, such as life satisfaction varying from 0 to 10 . Second, the wording in terms of frequency allows respondents to leave aside or weight differently recent events and temporary circumstances that instead affect significantly the overall evaluation of life satisfaction when asked in a specific moment in life. (Kahneman and Fredrickson 1993; Redelmeier and Kahneman 1996; Schwarz and Clore 1983). Our second variable of interest is the cognitive measure of life satisfaction obtained from the question "are you satisfied with your life?", where 0 means completely dissatisfied and 10 completely satisfied. Respondents are asked to give an overall judgment about their life in a backward-looking perspective, weighting recent and past events or circumstances. From the SHARE survey, we also extract data from specific modules that provide information on job status, health status and self-assessed condition, including life expectancy and social activities carried out by respondents. Due to the specific age composition of the SHARE survey, the question measuring respondents' life expectancy is of particular relevance. Independently from their age, respondents are asked to state the probability, from 0 to 100, that they will be alive in 10 years. This framing, which constitutes a unique feature of the SHARE survey, allows respondents to include in the judgment their subjective expectations on life expectancy. As well, the SHARE survey provides a set of eleven questions that allows us to construct an index of locus of control, that we calculate by means of a factor analysis. The concept of locus of control is due the Rotter's seminal work (1966) that describes it as a tool to understand the individuals' generalized expectancy about internal versus external control of reinforcement. Individuals with external locus of control tend to consider much of what happens to their life as driven by exogenous factors that do not fall under their control, like fate, luck or external circumstances determined by other people (family, boss) who have control over their own life. On the other hand, a prevailing internal locus of control signals the belief that one's own course of life events strictly depends on personal behavior and decision. The full set of variables collected from the SHARE database with descriptive statistics is listed in Table 1.

Our second source of data is the "EU Regional database" provided by the Quality of Government Institute (QoG) from which we obtain the European Quality of 
Table 1 Summary statistics

\begin{tabular}{|c|c|c|c|c|c|}
\hline Eurostat variables & Obs & Mean & Std. Dev. & Min & $\operatorname{Max}$ \\
\hline Log GDP per inhabitant NUTS2 & 39,022 & 10.23 & 0.35 & 9.67 & 11.16 \\
\hline Unemployment rate (age $15-74$ ) NUTS2 & 39,022 & 8.73 & 5.23 & 3.00 & 36.20 \\
\hline Early leavers rate (age 18-24) NUTS2 & 41,062 & 9.31 & 4.81 & 3.20 & 29.80 \\
\hline SHARE variables & Obs & Mean & Std. Dev. & Min & $\operatorname{Max}$ \\
\hline \multicolumn{6}{|l|}{ Age class } \\
\hline $50-55$ & 65,463 & 0.14 & 0.34 & 0 & 1 \\
\hline $56-60$ & 65,463 & 0.17 & 0.37 & 0 & 1 \\
\hline $61-65$ & 65,463 & 0.18 & 0.38 & 0 & 1 \\
\hline $66-70$ & 65,463 & 0.16 & 0.37 & 0 & 1 \\
\hline $71-75$ & 65,463 & 0.13 & 0.34 & 0 & 1 \\
\hline $76-80$ & 65,463 & 0.10 & 0.30 & 0 & 1 \\
\hline $81-85$ & 65,463 & 0.07 & 0.25 & 0 & 1 \\
\hline $86-90$ & 65,463 & 0.03 & 0.18 & 0 & 1 \\
\hline $91-95$ & 65,463 & 0.01 & 0.10 & 0 & 1 \\
\hline $95+$ & 65,463 & 0.00 & 0.04 & 0 & 1 \\
\hline \multicolumn{6}{|l|}{ Marital status } \\
\hline Married & 25,507 & 0.71 & 0.45 & 0 & 1 \\
\hline Registered partnership & 25,507 & 0.02 & 0.12 & 0 & 1 \\
\hline Separated & 25,507 & 0.13 & 0.11 & 0 & 1 \\
\hline Divorced & 25,507 & 0.08 & 0.27 & 0 & 1 \\
\hline Widowed & 25,507 & 0.13 & 0.34 & 0 & 1 \\
\hline Never married & 25,507 & 0.05 & 0.22 & 0 & 1 \\
\hline \multicolumn{6}{|l|}{ Employment status } \\
\hline Unemployed & 65,273 & 0.03 & 0.17 & 0 & 1 \\
\hline Employed & 65,273 & 0.28 & 0.45 & 0 & 1 \\
\hline Retired & 65,273 & 0.56 & 0.50 & 0 & 1 \\
\hline Sick or disabled & 65,273 & 0.04 & 0.19 & 0 & 1 \\
\hline Homemaker & 65,273 & 0.08 & 0.27 & 0 & 1 \\
\hline Other job & 65,273 & 0.01 & 0.10 & 0 & 1 \\
\hline \multicolumn{6}{|l|}{ Job type } \\
\hline Technician or associate professional & 10,256 & 0.09 & 0.29 & 0 & 1 \\
\hline Clerk & 10,256 & 0.18 & 0.38 & 0 & 1 \\
\hline Service, shop and market sales worker & 10,256 & 0.21 & 0.40 & 0 & 1 \\
\hline Skilled agricultural or fishery worker & 10,256 & 0.03 & 0.16 & 0 & 1 \\
\hline Craft and related trades worker & 10,256 & 0.09 & 0.28 & 0 & 1 \\
\hline Plant and machine operator or assembler & 10,256 & 0.05 & 0.22 & 0 & 1 \\
\hline Elementartary occupation & 10,256 & 0.08 & 0.28 & 0 & 1 \\
\hline Armed forces & 10,256 & 0.00 & 0.06 & 0 & 1 \\
\hline Legislator, senior official or manager & 10,256 & 0.11 & 0.31 & 0 & 1 \\
\hline Pofessionals & 10,256 & 0.16 & 0.36 & 0 & 1 \\
\hline Male & 66,221 & 0.44 & 0.50 & 0 & 1 \\
\hline Long-term disease & 66,041 & 0.51 & 0.50 & 0 & 1 \\
\hline
\end{tabular}


Table 1 (continued)

\begin{tabular}{|c|c|c|c|c|c|}
\hline Eurostat variables & Obs & Mean & Std. Dev. & Min & $\operatorname{Max}$ \\
\hline Free time & 21,019 & 132.85 & 13.87 & 78 & 168 \\
\hline \multicolumn{6}{|l|}{ Frequency of pray } \\
\hline Never & 64,538 & 47.53 & 0.50 & 0 & 1 \\
\hline Less than once a week & 64,538 & 14.05 & 0.35 & 0 & 1 \\
\hline Once a week & 64,538 & 6.83 & 0.25 & 0 & 1 \\
\hline A couple of times a week & 64,538 & 6.84 & 0.25 & 0 & 1 \\
\hline Once daily & 64,538 & 15.82 & 0.36 & 0 & 1 \\
\hline More than once daily & 64,538 & 8.93 & 0.28 & 0 & 1 \\
\hline \multicolumn{6}{|c|}{ Individual generativity potential variables } \\
\hline (Log)Income & 65,553 & 10.06 & 1.04 & 0.52 & 16.12 \\
\hline Years of education & 66,221 & 11.11 & 4.30 & 0 & 25 \\
\hline Self-assessed life expectancy & 58,711 & 63.34 & 29.77 & 0 & 100 \\
\hline \multicolumn{6}{|l|}{ Self-assessed health status } \\
\hline Poor & 66,035 & 0.11 & 0.31 & 0 & 1 \\
\hline Fair & 66,035 & 0.27 & 0.44 & 0 & 1 \\
\hline Good & 66,035 & 0.37 & 0.48 & 0 & 1 \\
\hline Very good & 66,035 & 0.17 & 0.38 & 0 & 1 \\
\hline Excellent & 66,035 & 0.08 & 0.27 & 0 & 1 \\
\hline \multicolumn{6}{|l|}{ Local generativity potential variables } \\
\hline EQI Corruption Index NUTS2 & 32,066 & 0.32 & 0.72 & -1.69 & 1.81 \\
\hline EQI Impartiality Index NUTS2 & 32,066 & 0.19 & 0.79 & -1.30 & 2.07 \\
\hline EQI Quality Index NUTS2 & 32,066 & 0.28 & 0.65 & -1.13 & 1.72 \\
\hline Economic Freedom Index NUTS0 & 63,622 & 70.62 & 5.10 & 60.60 & 81.00 \\
\hline \multicolumn{6}{|l|}{ Generativity in act variables } \\
\hline Voluntary and charity work & 64,783 & 0.18 & 0.38 & 0 & 1 \\
\hline Sport and social club & 64,783 & 0.30 & 0.46 & 0 & 1 \\
\hline Political activities & 64,783 & 0.06 & 0.24 & 0 & 1 \\
\hline Give help & 45,116 & 0.29 & 0.45 & 0 & 1 \\
\hline Give gift ( $250.00 €$ or more) & 44,606 & 0.29 & 0.46 & 0 & 1 \\
\hline Have children & 45,131 & 0.89 & 0.32 & 0 & 1 \\
\hline \multicolumn{6}{|l|}{ Generative components } \\
\hline Individual generativity potential & 65,979 & 6.08 & 1.24 & 1.48 & 9.56 \\
\hline Local generativity potential & 32,066 & 5.47 & 0.73 & 3.81 & 6.90 \\
\hline Generativity in act & 44,315 & 0.34 & 0.20 & 0 & 1 \\
\hline \multicolumn{6}{|l|}{ Locus of control variables } \\
\hline Age prevents from doing things & 64,437 & 2.32 & 1.05 & 1 & 4 \\
\hline Out of control & 64,030 & 2.09 & 0.99 & 1 & 4 \\
\hline Left out of things & 64,244 & 1.70 & 0.91 & 1 & 4 \\
\hline Family responsibilities prevent & 64,403 & 1.83 & 0.96 & 1 & 4 \\
\hline Shortage of money & 64,425 & 2.28 & 1.12 & 1 & 4 \\
\hline Do what you want & 64,317 & 3.25 & 0.92 & 1 & 4 \\
\hline Looking forward & 64,110 & 3.45 & 0.86 & 1 & 4 \\
\hline
\end{tabular}


Table 1 (continued)

\begin{tabular}{llcccc}
\hline Eurostat variables & Obs & Mean & Std. Dev. & Min & Max \\
\hline Look back with happiness & 64,153 & 3.40 & 0.76 & 1 & 4 \\
Feel full of energy & 64,442 & 3.17 & 0.87 & 1 & 4 \\
Feel full of opportunity & 63,834 & 3.14 & 0.88 & 1 & 4 \\
Future looks good & 63,577 & 3.08 & 0.91 & 1 & 4 \\
External LoC index & 64,259 & 2.04 & 0.65 & 1 & 4 \\
\hline
\end{tabular}

Government Index (EQI). ${ }^{10}$ It is the result of survey data collections on corruption and governance at NUTS2 level within the European Union, conducted in 2010 and 2013. The data merge either perception and experience of corruption with the public sector and contain information on how citizens consider various public sector services as impartially allocated and of good quality. The EQI index is extracted by a set of 16 questions regarding three main pillars: (1) quality, (2) impartiality and (3) corruption in three main public sector services: (1) education, (2) health and (3) law enforcement. Starting from microdata, the scores of each question are aggregated up to NUTS2 level and are then standardized. From this database, we extract the regional index for each of the three pillars and the overall EQI index. The full procedure applied to calculate the index is described in the OECD's Handbook on Constructing Composite Indicators (Nardo et al. 2005).

The third source of data is the Heritage Foundation which provides the Economic Freedom Index (EFI) at national level. This index created by the Wall Street Journal measures the degree of economic freedom across 186 countries. It reflects the individual fundamental right to control ones' own labor and property, decide to work, produce, consume and invest in the most preferred way without any coercion or constraint against freedom. The index scores from 0 and 100 and considers twelve different aspects of economic freedom over four main categories: (1) rule of law, (2) government size, (3) regulatory efficiency and (4) market openness. The final aggregate index is a weighted average where each of the twelve aspects is given equal weight. We use the index for the year 2013.

The last source of data we use in our study is the regional database of the Eurostat. ${ }^{11}$ We collect a set of variables at NUTS2 level to control for the main aspects of the socioeconomic context of the region where respondents live, relative to the year of the SHARE survey. Specifically, we include in our dataset the logarithmic transformation of the regional gross domestic product per inhabitant in PPP, the

\footnotetext{
10 The European Quality of Government Index (EQI) is the only existing measure of institutional quality built at regional level for the European Union. Institutional quality in the database is multidimensional and includes quality and impartiality of public service together with a corruption measure. Corruption perception in the region of residence is also measured. Data collection is funded by the European Commission.

${ }^{11}$ More specifically, we use the NUTS1, 2 and 3 levels of the Eurostat (the statistical office of the European Union) regional database.
} 
unemployment rate of the working-age population (aged from 15 to 74 years), and the share of early leavers from education and training activities (aged from 18 to 24).

\section{Descriptive statistics}

Descriptive statistics presented in Table 1 show that our SHARE sample is slightly unbalanced toward female gender (56\% of the sample). In spite of the age composition of our sample, only $11 \%$ of the respondents consider his/her own health status as poor. $27 \%$ deem it to be fair, and the remaining good (37\%), very good $(17 \%)$ or excellent (8\%). 65 percent of the interviewed have an age between 50 and 70 years. Still, life expectancy, as measured by the subjective probability that the respondents will be alive in the next ten years, independently from actual age, is on average around 63 percent. Respondents have 11 years of education on average. As of job status, 28 percent is still working, either as employers or employees. 56 percent have retired from work, while 3 percent result to be unemployed. Homemakers, unable to work because permanently sick or disabled and those who have a different working condition are, respectively, the 8, 4 and 1 percent of our sample. Roughly onefifth are service workers or employed in shops and market sales (21 percent). 5 percent works as plant and machine operator or assembler and 9\% involved in craft and related trade works. Only 3\% is a skilled agricultural or fishery worker. Technicians or associate professionals, professionals, and legislators or senior officials or managers are, respectively, the $9 \%, 16 \%$ and $11 \%$ of our sample. $18 \%$ covers clerical offices and $8 \%$ is employed in an elementary occupation. Less than 1 percent belongs to armed forces. Strictly related to the job type is the variable about free time during the week. It is obtained as the difference between the total number of hours available in a week (168) and working hours. On average, our respondents have $133 \mathrm{~h}$ a week of free time, implying an average of 5 working hours a day. The average logarithmic transformation of household yearly income, varying from 0.52 to 16.12 , is 10.06, corresponding approximately to 20,000 Euros. Concerning marital status, 73 percent of our respondents live with his/her spouse (71 percent married, 2 percent in a registered partnership). $13 \%$ are separated and $8 \%$ divorced. Those who never married constitute the minority of our sample, being only the 5\%. In total, $89 \%$ are parents, having at least one child, either natural or adopted. For what concerns social activities $18 \%$ are involved in voluntary or charity work and only $6 \%$ takes part in political activities. $30 \%$ instead declared to attend sport or social club and mostly the same percentage applies to those who reported to have supported friends or family members with physical help or a financial gift of at least $250,00 €(29 \%)$.

As of the regional variables, descriptive statistics show that the logarithmic transformation of GDP per inhabitant in PPP is around 10 (very close to the average household income of our sample). The richest region is Luxemburg, while the poorest is Calabria, southern Italy. Unemployment rate of the working-age population (15-74 years) averages at $8.7 \%$, with the highest value $(36.2 \%)$ registered in Andalusia region (south Spain) and the lowest (3\%) observed in Bayern region (southeast Germany). As of youth participation, measured by the percentage of early leavers from education or training courses of individuals aged from 18 to 24 years, the worst 
situation is in Spain (29.8\%), in the Balearic Islands. The leadership in this respect belongs to Prague region (central Czech Republic), which registered a share of early leavers of 3.2 percent. For what regards the standardized corruption index, the worst value (-1.69) belongs to Campania, south Italy, while the soundest region is Jutland (central Denmark). The best region in terms of quality of institutions is Flanders region, northern Belgium. The last place in this ranking belongs to Galicia region, in northwestern Spain. Regarding equal treatment of citizens, the best situation is in the Netherlands, Overijssel region (Eastern Netherlands), while the most unequal place is Calais (northern France). Finally, economic freedom index, calculated by Heritage Foundation at country level, is highest in Switzerland and lowest in Italy.

\subsection{The construction of the generative components}

As discussed in the previous sections of the paper we define three generativity dimensions: (1) individual generativity potential, (2) local generativity potential and (3) individual generativity in act.

In order to build the first generativity component, individual generativity potential, we use four items broadly describing individual sociodemographic characteristics. What we basically imply is that in order to be potentially generative an individual needs (1) good cultural background, expressed by the variable that records years of education, (2) adequate economic power, reflected in the logarithmic transformation of monthly household income, (3) good health conditions, derived from the question on self-assessed health status and (4) expectations about being alive in the next future, as expressed by the question in which respondents are asked to state the probability that they will be alive in 10 years. These four items are provided by the SHARE survey. To construct our first component of generativity power at individual level, we first create an index from 1 to 10 using the following equation:

$$
Y=\frac{X-\operatorname{Min}}{\operatorname{Max}-\operatorname{Min}} \times 9+1
$$

where, $Y$ is the score of the underlying (health, income, education) variable, ranging from 1 to $10, X$ is the value of the original variable observed in the database, and Min and Max are, respectively, the lowest and highest value of the variable in the database. We then sum up the scores of the four items and divide the total by the total number of non-missing values. Observations with two or more missing values are excluded from the sample. We decide to keep observations with just one missing value, and divide the sum by three, because of the many missing values present in SHARE. ${ }^{12}$ The final component varies from 1.24, signaling very limited generativity capabilities, to 9.56 , very high individual generativity potential, with a mean value of 6.08 and a standard deviation of 1.24 .

\footnotetext{
${ }^{12}$ In the robustness check section, we reconstruct the IGP adopting a different procedure, based on De Muro et al. (2011).
} 
The second dimension is local generativity power. In this respect, we argue that sound sociopolitical context facilitates actual generativity and high-quality institutions allow citizens to fully express their functionalities and capabilities. More specifically, we assume that corruption, lack of equal treatment and limits to economic freedom jeopardize growth and life flourishing as, among other things, they can discourage individual initiative to invest in human capital (Mo 2001). To capture the role played by the second generativity dimension we use four variables: the three pillar variables of the EQI index, measured at NUTS2 level, and the EFI index, only available at country level (see Sect. 4 for the description of these variables). Therefore, every region within the same country shares the same EFI index with the others. The three pillars of the EQI index provide us with compact measures of the level of corruption, equal treatment and institutional quality of the European regions. The EFI index instead reflects the extent to which citizens, within a given country, are free to decide upon their economic initiatives. To construct the final local generativity power component, we adopt the same procedure employed to create the component of individual generativity potential. We first score each single variable in the range from 1 to 10 (using Eq. 1), we then sum up the scores and divide the total by the number of non-missing variables. Again, observations with two or more missing values are excluded from the analysis. The result provides a compact index reflecting the overall generative potential at regional level. It averages at 5.47, with the lowest score at 3.81 (Champagne-Ardenne, northern France), the maximum at 6.90 (Overijssel region, Eastern Netherlands) and a standard deviation of 0.73 .

The last component of generativity aims to capture individual generativity in act. In order to build this factor, we exploit a set of five SHARE dummy questions in which respondents are asked to state their involvement in specific social activities during the previous 12 months, each of them therefore taking value 1 when the respondent is involved and 0 otherwise. More specifically, we use the questions on participation in vocational and charity work, sport and social club attendance, political activities engagement and provision of help or monetary support to friends or family members. Along with these questions, we also include a dummy variable taking into account biological generativity (having children or not, either adopted or natural). ${ }^{13}$ To create our index, we sum up all the answers given to these questions and divide the total by the number of non-missing variables. As for the other two components, due to the presence of many missing values, observations with 2 or more missing values have been excluded from the sample. The final index varies from 0 to 1 , with mean and median value of 0.34 and a standard deviation of $0.20{ }^{14}$ The region that enjoys the highest average value (0.54) is Utrecht, central Netherlands, while the region with lowest score (0.16) is Navarre, northern Spain. Correlation matrix presented in Table 2 shows pretty high positive correlation between Individual Generativity Potential (IGP)

\footnotetext{
13 To check internal consistency, we compute the Cronbach alpha. We obtain an acceptable alpha of 0.61 Davidshofer and Murphy (2005).

14 In the robustness check section, we apply different methods to reconstruct the GIA index and test our results.
} 
Table 2 Generative components. Correlation matrix

\begin{tabular}{llll}
\hline Components & $\begin{array}{l}\text { Individual generativity } \\
\text { potential }\end{array}$ & $\begin{array}{l}\text { Local generativity } \\
\text { potential }\end{array}$ & $\begin{array}{l}\text { Genera- } \\
\text { tivity in } \\
\text { act }\end{array}$ \\
\hline Individual generativity potential & 1.00 & 1.00 & \\
Local generativity potential & 0.20 & 0.17 & 1.00 \\
Generativity in act & 0.33 & & \\
\hline
\end{tabular}

and Local Generativity Potential (LGP) and Generativity In Act (GIA), 0.2 and 0.33 , respectively. The last two instead have a correlation of 0.17 . As expected, the stronger correlation is between individual generativity potential and individual generativity in act. As well, sounder regions allow individuals to be endowed with stronger generative potentials, that in turn translate into higher involvement in generative activities.

Along with the three components of generativity, we also investigate the role played by the type of job to proxy generativity in workplace. Our guess is that professional cirumstances might considerably affect the outcome of our dependent variable (eudaimonic happiness) through individual generativity in act. Differences in enjoyable free-time, workload, salaries and job satisfaction can alter notably the possibilities that individuals have to be generative so that, as a result, our findings might be driven by working conditions rather than by our components. To test our hypothesis, we construct a multinomial variable $(G e n J o b)$ with three categories capturing the potential generativity degree related with the job. The SHARE survey contains a question with 10 mutually exclusive job types that we classified as follows: (1) low generative jobs (Plant and machine operator or assembler, Elementary occupation, Armed forces), (2) mid-generative jobs (Technician, associate professional, Skilled agricultural or fishery worker, Service worker and shop and market sale, Craft and related trades worker) and (3) high generative jobs (Professional, Clerk, Legislator, senior official or manager). The underlying assumption is that jobs in the third group have more autonomy and power to influence lives of other human beings with personal decisions than those in the first group. We then used dummies capturing participation in the three groups as additional regressors in our analysis.

SHARE survey also allows us to construct a measure of individual Locus of Control (LoC). The list of variables we use to construct our measure of LoC is presented in Table 1 . They are all questions, with four possible mutually exclusive answers, varying from full agreement to full disagreement. To construct the index, we run a factor analysis, and take the score of the second factor to identify the external locus of control (as shown by Fig. 2 the second factor as expected is highly positively correlated with items such as "age prevents from doing things" "life is out of control," "I feel left out of things," family responsibilities prevent me from doing things"). Figures. 1 and 2 report the eigenvalues of the factor analysis and the factor loadings of the first two factors after varimax rotation, respectively. For reasons of space, we omit to report the tables with all the eigenvectors and eigenvalues of all the factors. 


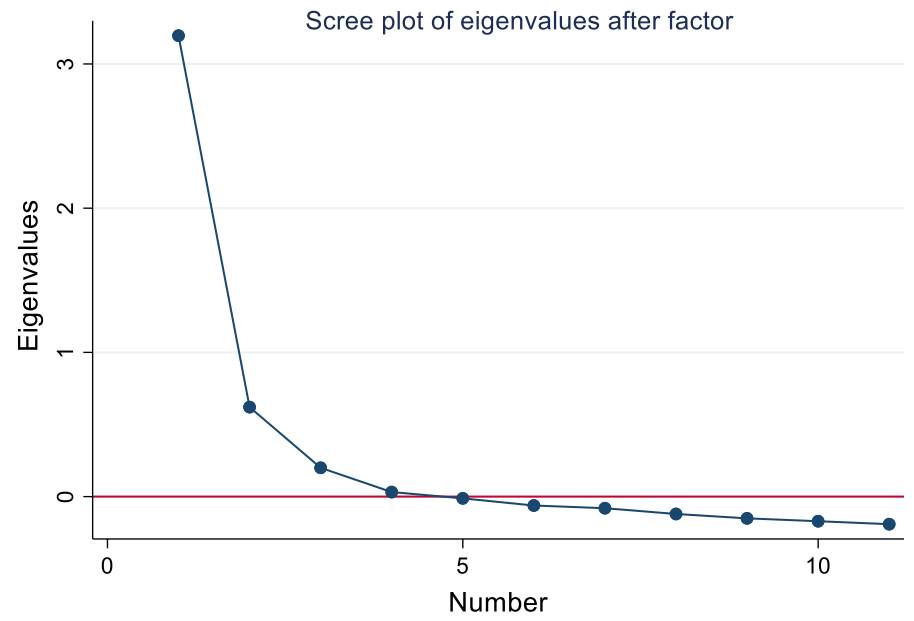

Fig. 1 Factor analysis. Screenplot of eigenvalues

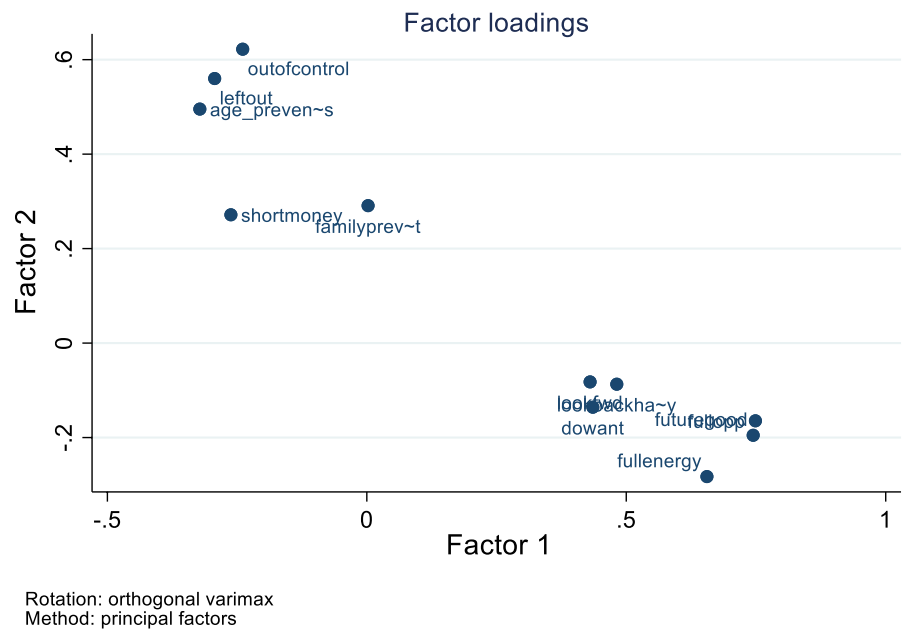

Fig. 2 Factor analysis. Factor loadings

\section{Econometric specification}

To investigate the effect of generativity elements on our dependent variables of subjective well-being, we estimate the following model, by means of an ordered logistic regression 


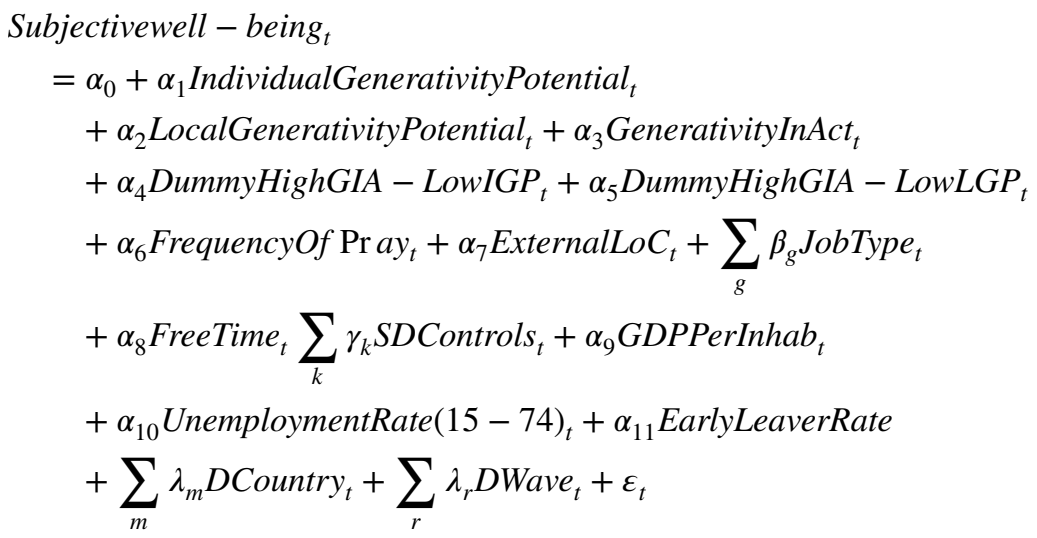

where the dependent categorical variables are eudaimonic well-being ("How often do you think your life has meaning?") 15 and life satisfaction ("Are you satisfied with your life?"), ${ }^{16}$ measured as explained in Sect. 4. In our first specification, we regress eudaimonic happiness and life satisfaction on the three generativity components. We then introduce additively two dummy variables (DummyHighGIALowIGP and Dummy HighGIA-LowLGP) that inform us about the effect of being involved in generative activities when generative (personal and political) potentials are relatively low (below the median value). The two dummy variables therefore take value 1 when Generativity in Act is above the median and Individual Generativity Potential (Local Generativity Potential) is under the median value, 0 otherwise. We further control for the level of religiosity and locus of control, to clean the effect of our components from these concurring factors. In the second specification, we include measures to observe the effect of generativity at workplace. As explained in the previous section, the idea behind this analysis is that job characteristics can affect directly generativity in act, especially among elders. First, some job types provide contingently more opportunities to be generative (being a teacher or a doctor for example) than others. To that aim, we include two additional explanatory variables capturing, respectively, mid-generative and high generative jobs as explained in Sect. 4.1 (with low generative jobs being the omitted benchmark) and a variable capturing leisure time (FreeTime). Sociodemographic controls (SDControls) include 10 five-year age class dummies (50-55 years omitted benchmark), a gender dummy (Male, being 1 for males and 0 for females), marital status dummies (one for each of the six categories: married, registered partnership, separated, which is our omitted benchmark, divorced, widowed and never married) and job status dummies (one for each of the six working conditions: employed, unemployed, retired, unable to work because permanently sick or disabled, homemaker, and other job, our omitted benchmark). Given the specific age composition of our sample, we further add a dummy variable to control for long-term illness. We also include three regional

\footnotetext{
15 The four available options ("often, sometimes, never, rarely").

16 Answers can range from 0 (completely unsatisfied) to 10 (fully satisfied).
} 
variables, measured at NUTS2 level, to control for objective economic conditions, that are the (log) GDP in PPP per inhabitant, the unemployment rate of the workingage population (i.e., from 15 to 74 years) and the share of young adult early leavers from education and training courses (aged 18 to 24 years). Finally, we include in our estimates country dummies to control for country effects. The inclusion of these dummies is important as it allows to clean our regression estimates from cultural or linguistic differences that can threaten comparability across respondents' answers about life sense and life satisfaction.

\subsection{Econometric findings}

Regression outputs with eudaimonic happiness and life satisfaction as dependent variables are presented in Tables 3 and 4, respectively. Starting with eudaimonic happiness, we find that respondents enjoy per se the two (local and personal) conditions of generativity potential, net of the inclusion of all sociodemographic and regional controls. We interpret these findings in two ways. First, both the personal and local potential generativity dimensions give satisfaction per se since individuals enjoy having a life full of opportunities (good education, good income, high expected life expectancy living in a region without corruption) Second, our two variables of (leisure and work) generativity in act do not capture all generativity dimensions and the generativity potential components proxy for other unobservable dimensions of generativity in act.

Our findings also show that generativity in act adds a positive and significant contribution to life sense beyond generativity in potential. More specifically, we also find that the size of the effect of Generativity In Act is more than double with respect to that of Individual Generativity Potential (Table 3 column 1-5). Overall, Generativity in Act results to be the strongest predictor of life sense, with a marginal effect of 0.195 , that is, a unit change of this indicator from its sample mean raises by 19.5 percent the odds of reporting the highest level of life sense (Table 5, column 1). Our results also show a "support effect" of high involvement in generative activities when individual generative potential is scarce. Being highly engaged when Individual Generativity Power is relatively low (below the median value) increases the log odds of reporting the highest level of life sense by 0.14 . Conversely, highly generative individuals suffer from living in areas with low generative potential and this contributes negatively to their life sense. In general, Local Generativity Potential is less correlated with individual eduaimonic happiness and loses significance in the full model, when we include locus of control as additional regressor (Table 3 column 5). Control variables behave in the expected direction. Male gender is negatively correlated with life sense. Being employed affects positively the probability to report the highest level of life sense, and relational success as manifested by sharing life with a partner, either in a marriage or in a registered partnership, correlates significantly and positively with eudaimonic happiness. On average, aging (net of the effect of health conditions also captured by our regressors) increases the perception of a meaningful life until it reaches the peak at $80-85$ years. After that age, the coefficients loose significance. 
Table 3 The determinants of subjective well-being

\begin{tabular}{|c|c|c|c|c|c|}
\hline & (1) & (2) & (3) & (4) & (5) \\
\hline Individual generativity potential (IGP) & $\begin{array}{l}0.496 * * * \\
(0.026)\end{array}$ & $\begin{array}{l}0.515^{* * *} \\
(0.027)\end{array}$ & $\begin{array}{l}0.519 * * * \\
(0.028)\end{array}$ & $\begin{array}{l}0.522 * * * \\
(0.028)\end{array}$ & $\begin{array}{l}0.472 * * * \\
(0.029)\end{array}$ \\
\hline Local generativity potential (LGP) & $\begin{array}{c}0.195 \\
(0.143)\end{array}$ & $\begin{array}{c}0.194 \\
(0.143)\end{array}$ & $\begin{array}{c}0.141 \\
(0.144)\end{array}$ & $\begin{array}{c}0.141 \\
(0.145)\end{array}$ & $\begin{array}{c}0.122 \\
(0.148)\end{array}$ \\
\hline Generativity in act (GIA) & $\begin{array}{l}1.274 * * * \\
(0.138)\end{array}$ & $\begin{array}{l}1.114 * * * \\
(0.157)\end{array}$ & $\begin{array}{l}1.232 * * * \\
(0.163)\end{array}$ & $\begin{array}{l}1.206^{* * *} \\
(0.164)\end{array}$ & $\begin{array}{l}1.272^{* * *} \\
(0.168)\end{array}$ \\
\hline DummyHighGIA-LowIGP & & $\begin{array}{l}0.190^{* *} \\
(0.092)\end{array}$ & $\begin{array}{l}0.224^{* *} \\
(0.093)\end{array}$ & $\begin{array}{l}0.220 * * \\
(0.094)\end{array}$ & $\begin{array}{l}0.197 * * \\
(0.096)\end{array}$ \\
\hline DummyHighGIA-LowLGP & & & $\begin{array}{c}-0.348^{* * *} \\
(0.124)\end{array}$ & $\begin{array}{c}-0.357 * * * \\
(0.125)\end{array}$ & $\begin{array}{c}-0.328 * * \\
(0.127)\end{array}$ \\
\hline Frequency of pray & & & & $\begin{array}{l}0.069 * * * \\
(0.015)\end{array}$ & $\begin{array}{l}0.081 * * * \\
(0.015)\end{array}$ \\
\hline External LoC & & & & & $\begin{array}{c}-0.451^{* * *} \\
(0.036)\end{array}$ \\
\hline Male & $\begin{array}{c}-0.172 * * * \\
(0.051)\end{array}$ & $\begin{array}{c}-0.175^{* * *} \\
(0.051)\end{array}$ & $\begin{array}{c}-0.177 * * * \\
(0.051)\end{array}$ & $\begin{array}{c}-0.129 * * \\
(0.052)\end{array}$ & $\begin{array}{c}-0.115^{* *} \\
(0.054)\end{array}$ \\
\hline \multicolumn{6}{|c|}{ Job status: omitted benchmark "other type of job status" } \\
\hline Employed & $\begin{array}{c}0.415^{*} \\
(0.246)\end{array}$ & $\begin{array}{c}0.415^{*} \\
(0.246)\end{array}$ & $\begin{array}{c}0.425^{*} \\
(0.246)\end{array}$ & $\begin{array}{c}0.440 * \\
(0.247)\end{array}$ & $\begin{array}{c}0.460 * \\
(0.251)\end{array}$ \\
\hline Unemployed & $\begin{array}{c}-0.209 \\
(0.264)\end{array}$ & $\begin{array}{c}-0.211 \\
(0.265)\end{array}$ & $\begin{array}{c}-0.201 \\
(0.264)\end{array}$ & $\begin{array}{c}-0.205 \\
(0.265)\end{array}$ & $\begin{array}{c}-0.136 \\
(0.270)\end{array}$ \\
\hline Retired & $\begin{array}{c}0.011 \\
(0.246)\end{array}$ & $\begin{array}{c}0.008 \\
(0.246)\end{array}$ & $\begin{array}{c}0.021 \\
(0.246)\end{array}$ & $\begin{array}{c}0.035 \\
(0.247)\end{array}$ & $\begin{array}{c}0.071 \\
(0.251)\end{array}$ \\
\hline Sick or disabled & $\begin{array}{c}-0.357 \\
(0.261)\end{array}$ & $\begin{array}{c}-0.360 \\
(0.261)\end{array}$ & $\begin{array}{c}-0.351 \\
(0.261)\end{array}$ & $\begin{array}{c}-0.349 \\
(0.262)\end{array}$ & $\begin{array}{c}-0.206 \\
(0.266)\end{array}$ \\
\hline Homemaker & $\begin{array}{c}-0.027 \\
(0.259)\end{array}$ & $\begin{array}{c}-0.028 \\
(0.259)\end{array}$ & $\begin{array}{c}-0.014 \\
(0.259)\end{array}$ & $\begin{array}{c}-0.035 \\
(0.260)\end{array}$ & $\begin{array}{c}0.029 \\
(0.265)\end{array}$ \\
\hline \multicolumn{6}{|c|}{ Marital status: omitted benchmark "separated" } \\
\hline Married & $\begin{array}{l}0.567 * * * \\
(0.175)\end{array}$ & $\begin{array}{l}0.567 * * * \\
(0.175)\end{array}$ & $\begin{array}{l}0.560 * * * \\
(0.175)\end{array}$ & $\begin{array}{l}0.588^{* * *} \\
(0.176)\end{array}$ & $\begin{array}{l}0.459 * * \\
(0.183)\end{array}$ \\
\hline Never married & $\begin{array}{c}0.046 \\
(0.190)\end{array}$ & $\begin{array}{c}0.040 \\
(0.190)\end{array}$ & $\begin{array}{c}0.048 \\
(0.190)\end{array}$ & $\begin{array}{c}0.069 \\
(0.191)\end{array}$ & $\begin{array}{c}-0.036 \\
(0.199)\end{array}$ \\
\hline Registered partnership & $\begin{array}{c}0.514^{*} \\
(0.266)\end{array}$ & $\begin{array}{c}0.515^{*} \\
(0.266)\end{array}$ & $\begin{array}{c}0.515^{*} \\
(0.266)\end{array}$ & $\begin{array}{c}0.558 * * \\
(0.267)\end{array}$ & $\begin{array}{c}0.422 \\
(0.274)\end{array}$ \\
\hline Divorced & $\begin{array}{c}-0.089 \\
(0.183)\end{array}$ & $\begin{array}{l}-0.087 \\
(0.183)\end{array}$ & $\begin{array}{r}-0.094 \\
(0.183)\end{array}$ & $\begin{array}{c}-0.050 \\
(0.184)\end{array}$ & $\begin{array}{c}-0.191 \\
(0.191)\end{array}$ \\
\hline Widowed & $\begin{array}{c}0.194 \\
(0.183)\end{array}$ & $\begin{array}{c}0.196 \\
(0.183)\end{array}$ & $\begin{array}{c}0.191 \\
(0.183)\end{array}$ & $\begin{array}{c}0.206 \\
(0.184)\end{array}$ & $\begin{array}{c}0.067 \\
(0.191)\end{array}$ \\
\hline Long-term illness & $\begin{array}{c}-0.017 \\
(0.054)\end{array}$ & $\begin{array}{c}-0.017 \\
(0.054)\end{array}$ & $\begin{array}{c}-0.016 \\
(0.054)\end{array}$ & $\begin{array}{c}-0.023 \\
(0.054)\end{array}$ & $\begin{array}{c}0.041 \\
(0.056)\end{array}$ \\
\hline Log GDP per inhabitant & $\begin{array}{c}-0.122 \\
(0.105)\end{array}$ & $\begin{array}{c}-0.130 \\
(0.105)\end{array}$ & $\begin{array}{c}-0.129 \\
(0.105)\end{array}$ & $\begin{array}{c}-0.148 \\
(0.105)\end{array}$ & $\begin{array}{c}-0.073 \\
(0.108)\end{array}$ \\
\hline
\end{tabular}


Table 3 (continued)

(1)

(2)

(3)

(4)

(5)

\begin{tabular}{lccccc}
\hline Unemployment rates (15-74) & 0.004 & 0.004 & 0.004 & 0.004 & 0.008 \\
& $(0.014)$ & $(0.014)$ & $(0.014)$ & $(0.014)$ & $(0.014)$ \\
\% of early leavers from educ. and & -0.002 & -0.002 & -0.001 & 0.001 & 0.001 \\
train. (18-24) & $(0.015)$ & $(0.015)$ & $(0.015)$ & $(0.015)$ & $(0.015)$ \\
Age dummies & Yes & Yes & Yes & Yes & Yes \\
Dummy countries & Yes & Yes & Yes & Yes & Yes \\
Pseudo $R$-squared & 0.117 & 0.117 & 0.117 & 0.119 & 0.131 \\
No. of observations & 10,390 & 10,390 & 10,390 & 10,342 & 10,043 \\
\hline
\end{tabular}

The role of generativity components (dependent variable: life sense)

Dependent variable: "How often do you think your life has meaning?" The four available answers are: often, sometimes, never, rarely. DummyHighGIA-LowIGP=Dummy for high Generativity In Act/Low Individual Generativity Power; DummyHighGIA-LowLGP=Dummy for high Generativity In Act/ Low Local Generativity Power. Ordered logistic regression; Robust standard errors in parentheses; *** $p<0.01, * * p<0.05, * p<0.1$

We repeat our estimations by replacing eudaimonic happiness with the cognitive measure of life satisfaction. Overall results (Table 4) are consistent with our previous findings, with some differences in magnitudes. Confirming our first and second hypotheses, each of the three components correlates positively with life satisfaction, even though the leading position in terms of magnitude is now taken by Individual Generativity Potential. This implies that generativity in act plays a more important role in determining higher levels of life sense than life satisfaction. Still, the magnitude of the effect of Generativity in Act is 50 percent higher when we include the index of external LoC in our regression (columns 4 and 5 of Table 4), thus confirming our hypothesis $\mathrm{Ho}_{4}$ about the trade-off between "freedom of" and "freedom for" when investigating the determinants of life satisfaction. The null hypothesis on the absence of a significance difference between the Generativity in Act coefficients in columns 4 and 5 (i.e., in specifications with/without the locus of control variable) is rejected (Chi squared 30.69, $p$ value 0.000). One of the main drivers of this result lays in the interplay with family sphere and more in general control over time. Feeling the burden of family responsibilities and duties as threatening individual freedom, coupled with high commitment in socially generative activities, drives externally the locus of control, thereby determining the trade-off. In fact, highly engaged individuals, on average, believe that family responsibilities prevent them to do the things they want to do (Table 6). These findings can be interpreted in light of the higher commitment and effort levels required by actual generativity.

Stronger differences with respect to life sense emerge in the set of controls. Regarding marital status, all the categories (against the omitted benchmark of separated) are positively and significantly correlated with life satisfaction. Concerning job status instead we observe that unemployment is the only condition that relates negatively with our dependent variable. By contrast, having retired from work or being a homemaker, along with being employed, have a better positive effect on life 


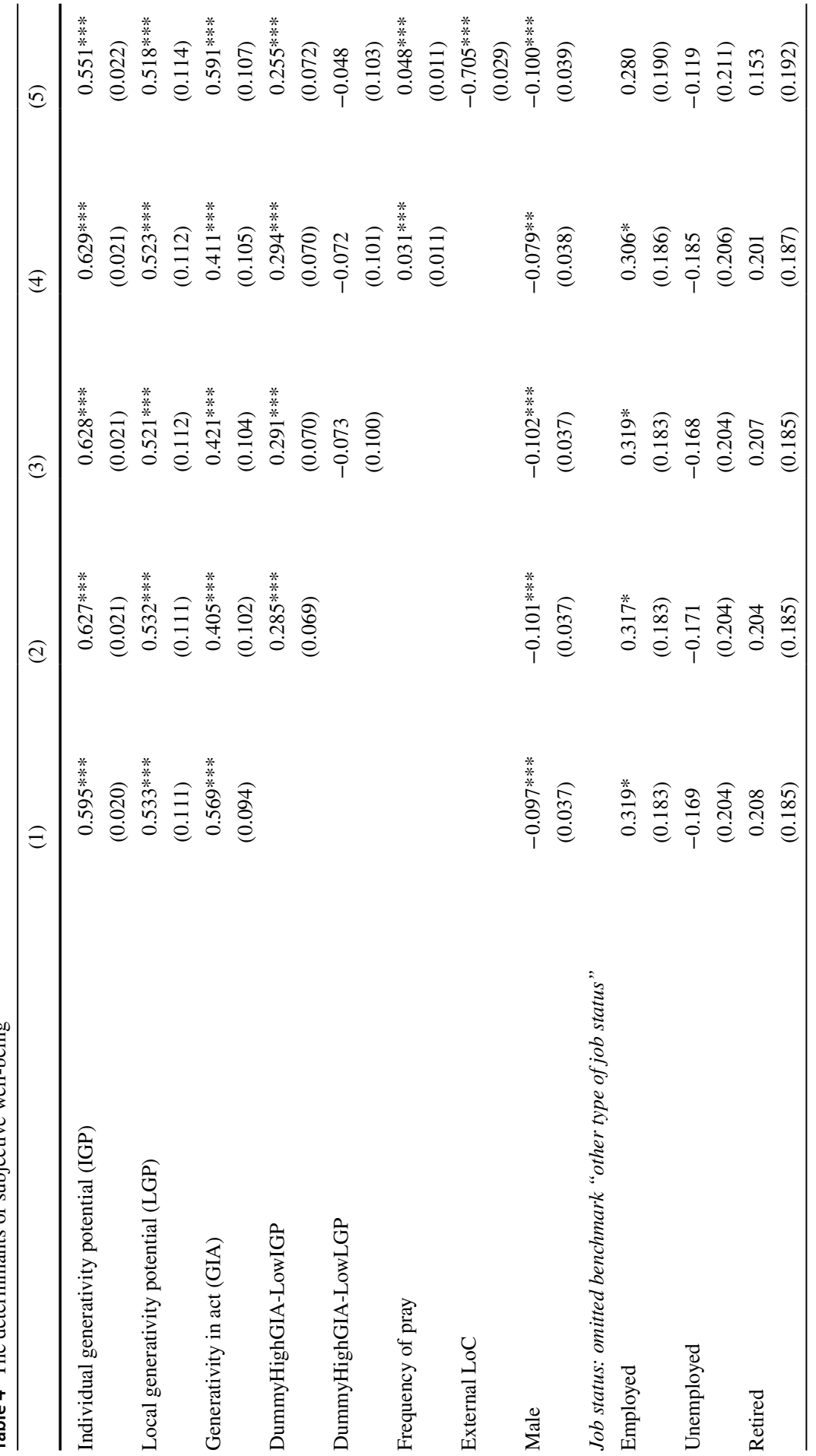




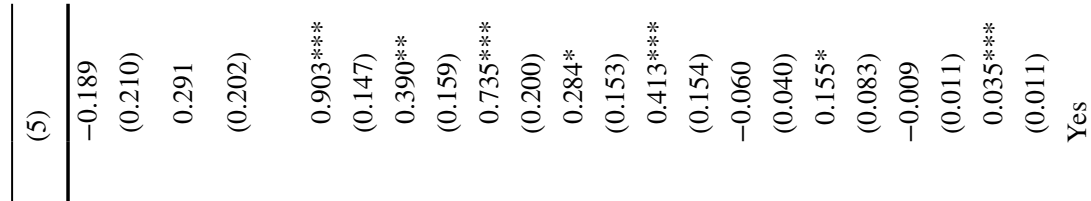

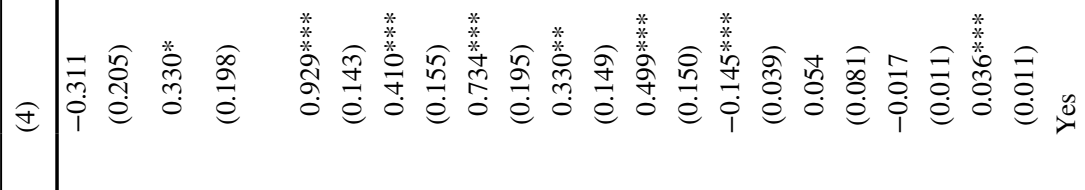

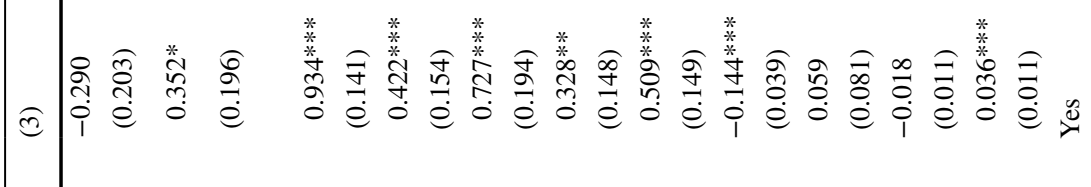

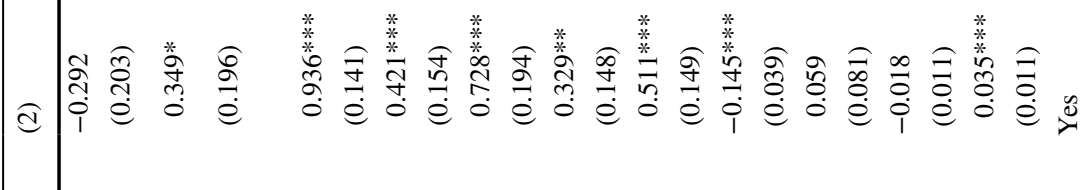

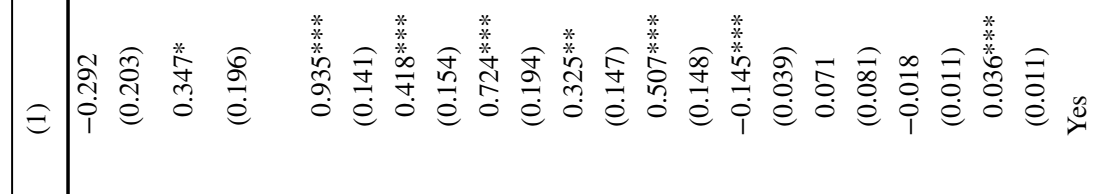

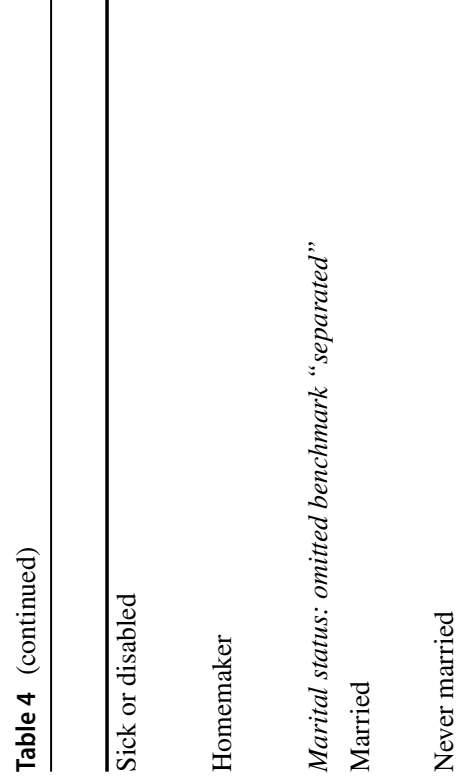

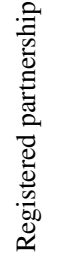

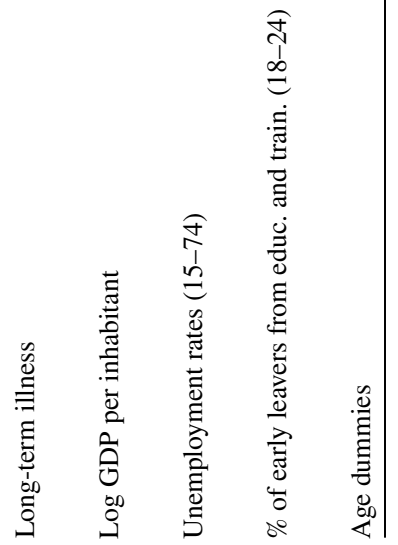




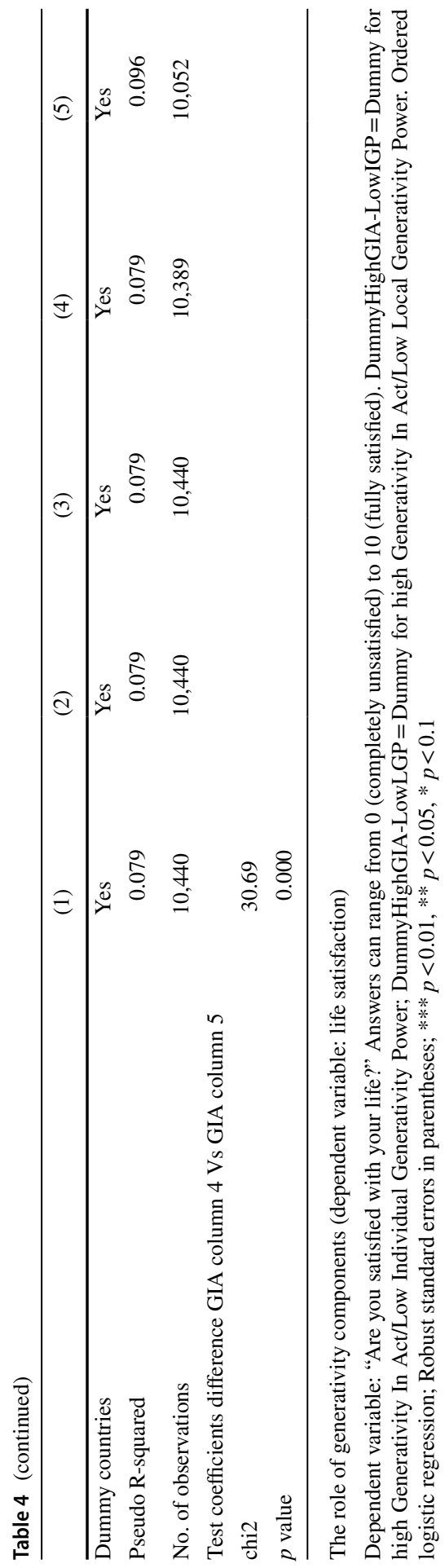


Table 5 The determinants of subjective well-being
(1)

(2)

\begin{tabular}{lcc}
\hline Individual generativity potential (IGP) & $0.072^{* * *}$ & $0.066^{* * *}$ \\
& $(0.004$ & $(0.003)$ \\
Local generativity potential (LGP) & 0.019 & $0.062^{* * *}$ \\
& $(0.023)$ & $(0.014)$ \\
Generativity in act (GIA) & $0.195^{* * *}$ & $0.071^{* * *}$ \\
& $(0.026)$ & $(0.013)$ \\
DummyHighGIA-LowIGP & $0.030^{* *}$ & $0.031^{* * *}$ \\
& $(0.015)$ & $(0.009)$ \\
DummyHighGIA-LowLGP & $-0.050^{* *}$ & $-0.006^{* * *}$ \\
& $(0.019)$ & $(0.012)$ \\
Frequency of pray & $-0.069^{* * *}$ & $-0.085^{* * *}$ \\
& $(0.005)$ & $(0.004)$ \\
\hline
\end{tabular}

The role of generativity components. Marginal effects

Marginal effects after ordered logistic regression on the probability to achieve the highest level of life sense ("Often", column (1)) and highest level of life satisfaction ("10", column (2)). Reference models: columns 5 of Tables 3 and Table 4 . Robust standard errors in parentheses; $* * * p<0.01$, ** $p<0.05, * p<0.1$

satisfaction than the omitted benchmark of the unemployment status. Suffering from long-term illness also enters the relationship in negative terms.

In the second specification we reestimate our model including the variables representing generativity in professional life and free time disposal. Results are reported in Table 7 and Table 8 with life sense and life satisfaction as dependent variables, respectively. Our main findings are confirmed in this specification as well. Jobs characterized by high generativity potential are strongly and positively correlated with life meaning and life satisfaction (low generative job as omitted benchmark) with the coefficient of the full model more relevant for the former (columns 5 of Tables 7 and 8). Still, Generativity In Act maintains its effect on our dependent variables net of the job type. Our findings on the trade-off between "freedom for" and "freedom of" (on life satisfaction) are also confirmed since the coefficient of Generativity in Act is markedly higher when we add the external locus of control among regressors.

\section{Robustness checks}

To corroborate the validity of our results, we perform a series of robustness checks, reported in Appendix A. One of the main limits of our indicator of individual generativity in act is that being constructed as a sum of different dummy variables, it gives equal weight to very different items, assuming that they all share the same correlation with the generativity dimension. In addition, our generativity in act index does not differentiate across items that can have different effects on personal and others' life meaning and life satisfaction. For example, participating to social club or practicing sports can be perceived as generative from the individual who is engaged 


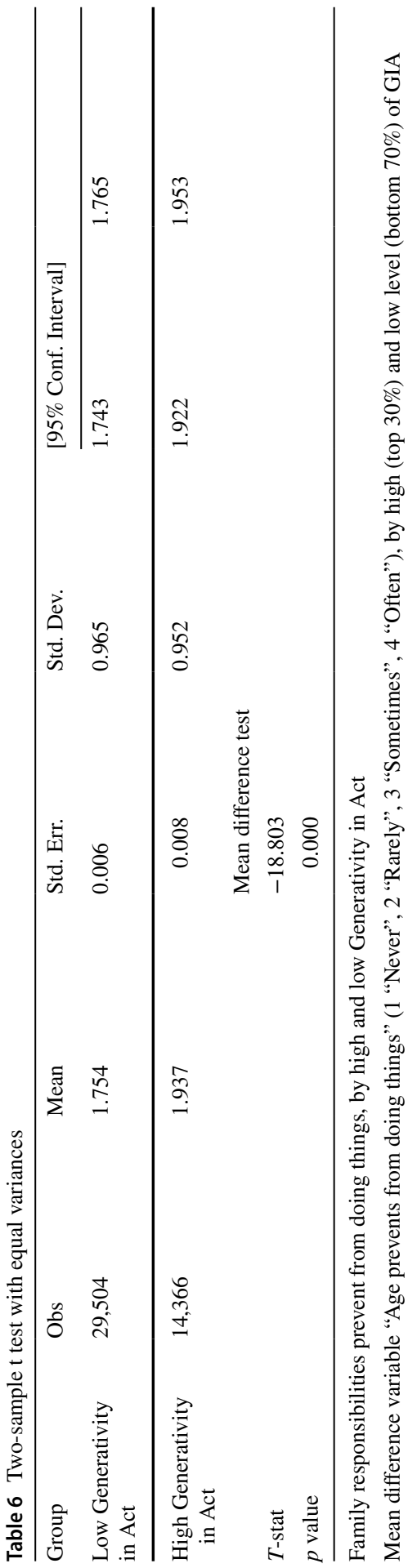


Table 7 The determinants of subjective well-being

\begin{tabular}{|c|c|c|c|c|c|}
\hline & (1) & (2) & (3) & (4) & (5) \\
\hline Individual generativity potential (IGP) & $\begin{array}{l}0.496 * * * \\
(0.026)\end{array}$ & $\begin{array}{l}0.519 * * * \\
(0.028)\end{array}$ & $\begin{array}{l}0.493 * * * \\
(0.057)\end{array}$ & $\begin{array}{l}0.486 * * * \\
(0.057)\end{array}$ & $\begin{array}{l}0.424 * * * \\
(0.060)\end{array}$ \\
\hline Local generativity potential (LGP) & $\begin{array}{c}0.195 \\
(0.143)\end{array}$ & $\begin{array}{c}0.141 \\
(0.144)\end{array}$ & $\begin{array}{c}0.101 \\
(0.296)\end{array}$ & $\begin{array}{c}0.147 \\
(0.297)\end{array}$ & $\begin{array}{c}0.204 \\
(0.301)\end{array}$ \\
\hline Generativity in Act (GIA) & $\begin{array}{l}1.274 * * * \\
(0.138)\end{array}$ & $\begin{array}{l}1.232 * * * \\
(0.163)\end{array}$ & $\begin{array}{l}1.262 * * * \\
(0.286)\end{array}$ & $\begin{array}{l}1.257 * * * \\
(0.287)\end{array}$ & $\begin{array}{l}1.219 * * * \\
(0.293)\end{array}$ \\
\hline DummyHighGIA-LowIGP & & $\begin{array}{l}0.224 * * \\
(0.093)\end{array}$ & $\begin{array}{c}0.320 \\
(0.199)\end{array}$ & $\begin{array}{c}0.320 \\
(0.200)\end{array}$ & $\begin{array}{c}0.355^{*} \\
(0.205)\end{array}$ \\
\hline DummyHighGIA-LowLGP & & $\begin{array}{c}-0.348 * * * \\
(0.124)\end{array}$ & $\begin{array}{c}-0.668 * * * \\
(0.237)\end{array}$ & $\begin{array}{c}-0.653 * * * \\
(0.238)\end{array}$ & $\begin{array}{c}-0.588^{* *} \\
(0.243)\end{array}$ \\
\hline \multicolumn{6}{|c|}{ Generative job classes; omitted benchmark "Low generative jobs" } \\
\hline Mid-generative job & & & $\begin{array}{c}0.156 \\
(0.139)\end{array}$ & $\begin{array}{c}0.154 \\
(0.139)\end{array}$ & $\begin{array}{c}0.214 \\
(0.142)\end{array}$ \\
\hline High-generative job & & & $\begin{array}{l}0.352 * * \\
(0.150)\end{array}$ & $\begin{array}{l}0.333 * * \\
(0.150)\end{array}$ & $\begin{array}{l}0.456^{* * * *} \\
(0.154)\end{array}$ \\
\hline Free time & & & & $\begin{array}{c}-0.010^{* * *} \\
(0.004)\end{array}$ & $\begin{array}{c}-0.011^{* * * *} \\
(0.004)\end{array}$ \\
\hline Frequency of pray & & & & & $\begin{array}{l}0.079 * * \\
(0.032)\end{array}$ \\
\hline External LoC & & & & & $\begin{array}{c}-0.499 * * * \\
(0.073)\end{array}$ \\
\hline Age dummies & Yes & Yes & Yes & Yes & Yes \\
\hline Controls & Yes & Yes & Yes & Yes & Yes \\
\hline Dummy countries & Yes & Yes & Yes & Yes & Yes \\
\hline Pseudo $R$-squared & 0.117 & 0.117 & 0.105 & 0.106 & 0.117 \\
\hline No. of observations & 10,390 & 10,390 & 3798 & 3777 & 3712 \\
\hline
\end{tabular}

The role of generativity jobs (dependent variable: life sense)

Dependent variable: "How often do you think your life has meaning?" The four available answers are: often, sometimes, never, rarely. DummyHighGIA-LowIGP=Dummy for high Generativity In Act/Low Individual Generativity Power; DummyHighGIA-LowLGP=Dummy for high Generativity In Act/ Low Local Generativity Power; Ordered logistic regression; Robust standard errors in parentheses; *** $p<0.01, * * p<0.05, * p<0.1$

in it, and can impact positively on her life sense and satisfaction. At the same time, this activity could not be received as generative by others and could have a much lower effect on others' life sense and life satisfaction than participating in vocational or charity works or giving help to friends and relatives. To tackle these issues, we exploit the household dimension of our data. We compute the correlation coefficients between activities included in the generativity in act index and the partners' life sense and satisfaction. We use the coefficients obtained as weights to recompute the index. This procedure allows us to give more weight to activities that have higher correlation with others' life sense and satisfaction and that therefore might be intended as being more generative. Results are reported in Tables 9 and 10 for 
Table 8 The determinants of subjective well-being

\begin{tabular}{|c|c|c|c|c|c|}
\hline & (1) & $(2)$ & (3) & (4) & (5) \\
\hline $\begin{array}{l}\text { Individual generativity potential } \\
\text { (IGP) }\end{array}$ & $\begin{array}{l}0.595 * * * \\
(0.020)\end{array}$ & $\begin{array}{l}0.628 * * * \\
(0.021)\end{array}$ & $\begin{array}{l}0.639 * * * \\
(0.039)\end{array}$ & $\begin{array}{l}0.632 * * * \\
(0.039)\end{array}$ & $\begin{array}{l}0.542 * * * \\
(0.040)\end{array}$ \\
\hline $\begin{array}{l}\text { Local generativity potential } \\
\text { (LGP) }\end{array}$ & $\begin{array}{l}0.533 * * * \\
(0.111)\end{array}$ & $\begin{array}{l}0.521 * * * \\
(0.112)\end{array}$ & $\begin{array}{l}0.387 * * \\
(0.196)\end{array}$ & $\begin{array}{l}0.410^{* *} \\
(0.196)\end{array}$ & $\begin{array}{l}0.467 * * \\
(0.200)\end{array}$ \\
\hline Generativity in Act (GIA) & $\begin{array}{l}0.569 * * * \\
(0.094)\end{array}$ & $\begin{array}{l}0.421^{* * * *} \\
(0.104)\end{array}$ & $\begin{array}{l}0.477 * * * \\
(0.161)\end{array}$ & $\begin{array}{l}0.473 * * * \\
(0.162)\end{array}$ & $\begin{array}{l}0.709 * * * \\
(0.165)\end{array}$ \\
\hline DummyHighGIA-LowIGP & & $\begin{array}{l}0.291 * * * \\
(0.070)\end{array}$ & $\begin{array}{c}0.156 \\
(0.135)\end{array}$ & $\begin{array}{c}0.145 \\
(0.136)\end{array}$ & $\begin{array}{c}0.109 \\
(0.138)\end{array}$ \\
\hline DummyHighGIA-LowLGP & & $\begin{array}{c}-0.073 \\
(0.100)\end{array}$ & $\begin{array}{c}-0.311^{*} \\
(0.178)\end{array}$ & $\begin{array}{r}-0.298^{*} \\
(0.178)\end{array}$ & $\begin{array}{r}-0.244 \\
(0.182)\end{array}$ \\
\hline \multicolumn{6}{|c|}{ Generative job classes; omitted benchmark "Low generative jobs) } \\
\hline Mid-generative job & & & $\begin{array}{c}0.128 \\
(0.106)\end{array}$ & $\begin{array}{c}0.139 \\
(0.107)\end{array}$ & $\begin{array}{l}0.197 * \\
(0.108)\end{array}$ \\
\hline High-generative job & & & $\begin{array}{c}0.201 * \\
(0.109)\end{array}$ & $\begin{array}{c}0.199 * \\
(0.109)\end{array}$ & $\begin{array}{l}0.303 * * * \\
(0.111)\end{array}$ \\
\hline Free time & & & & $\begin{array}{r}-0.003 \\
(0.003)\end{array}$ & $\begin{array}{r}-0.003 \\
(0.003)\end{array}$ \\
\hline Frequency of pray & & & & & $\begin{array}{l}0.041 * * \\
(0.020)\end{array}$ \\
\hline External LoC & & & & & $\begin{array}{c}-0.817 * * * \\
(0.051)\end{array}$ \\
\hline Age dummies & Yes & Yes & Yes & Yes & Yes \\
\hline Controls & Yes & Yes & Yes & Yes & Yes \\
\hline Dummy countries & Yes & Yes & Yes & Yes & Yes \\
\hline Pseudo R-squared & 0.079 & 0.079 & 0.076 & 0.075 & 0.096 \\
\hline No. of observation & 10,440 & 10,440 & 3810 & 3789 & 3717 \\
\hline
\end{tabular}

The role of generativity jobs (dependent variable: life satisfaction)

Dependent variable: "Are you satisfied with your life?" Answers can range from 0 (completely unsatisfied) to 10 (fully satisfied). DummyHighGIA-LowIGP=Dummy for high Generativity In Act/Low Individual Generativity Power; DummyHighGIA-LowLGP = Dummy for high Generativity In Act/ Low Local Generativity Power; Ordered logistic regression; Robust standard errors in parentheses; *** $p<0.01, * * p<0.05, * p<0.1$

eudaimonic happiness and life satisfaction, respectively, confirm our preliminary findings. Generativity in Act confirms to be the strongest driver for life sense (and not for life satisfaction) and to make it grow when Individual Generativity Power is scarce. We also support the hypothesis of the trade-off between "freedom of" and "freedom for" with respect life satisfaction. When controlling for locus of control in fact the coefficient of the Generativity in Act coefficient is significantly higher.

Further, in our base specification, we do not exploit the degree of engagement in each activity. The base specification therefore assumes that higher levels of engagement in generative activities have the same effect of lower levels. Nonetheless, SHARE survey asks respondents to state the frequency with which each activity is done (i.e., less than every month, almost every month, almost every week, almost daily). We give answers scores from 1 to 4 and reconstruct the individual generativity component as in the procedure reported in Sect. 4.1. This procedure allows to 
differentiate across individuals relying on the engagement dimension, giving higher value of generativity in act to individuals who engage more frequently in generative activities. Tables 11 and 12 report the results obtained for life sense and life satisfaction. Also, in this robustness check out preliminary findings remain confirmed. ${ }^{17}$

In addition, to reflect more faithfully the Generative Behavior Checklist in a further robustness check, we reconstruct the generativity in act index including two additional variables (i.e., reading books and looking after grandchildren) that can be matched with activities in the checklist. In particular, the activities included in the GBC are reading novel, and reading a story to a child. Although different, we believe that the two additional activities included in the index could proxy well those listed in the GBC. Results reported in Tables 13 and 14 show that our main findings remain consistent with our base specification.

Further, we check with bootstrap estimates whether our results are robust when we depart from the normality assumption on our dependent variable. In order to select the optimal number of bootstrap replications we follow the DavidsonMacKinnon (2000) procedure that fixes at 491 the number of replications that ensure that conflicts between the predicted and the actual $p$ value are just 0.0015 . Hence, the probability of having a downward bias in our bootstrapped standard errors is extremely low with this number of replications. Our main findings are unchanged with bootstrapped estimates (Tables 15 and 16).

Moreover, we test whether our most important findings depend on some outlier countries with the DFBETA test. More specifically, following the approach of Frey and Stutzer (2000) and Otterbach (2010), we consider the coefficient of our variable of interest in the fully augmented specification and compare it with the coefficient estimate when omitting one different country at a time. We then compute the difference of the coefficients divided by the second regression standard error, as expressed in the following formula:

$$
\operatorname{DFBETA}_{i, k}=\frac{\beta_{k}-\beta_{k(-i)}}{s e_{k(-i)}}
$$

where $\beta_{k}$ is the coefficient of the fully augmented regression, $\beta_{k(-i)}$ the coefficient of the regression where country $i$ is omitted from the sample, and $s e_{k(-i)}$ its standard error. Belsley et al. (1980) calculate that the significance of the considered regressor does not depend crucially from the omitted country if the value of the DFBETA statistics is below the 1.96 threshold. We apply the same test to the gender dimension. Our findings show that this is the case both for country and gender (with the only exception of Germany affecting strongly the result on life satisfaction). Results are reported from Tables 17, 18, 19, 20.

\footnotetext{
17 We also test our results substituting weights based on frequency with weights based on the level of satisfaction with the activities undertaken. SHARE asks respondents to give an overall assessment about their level of satisfaction with the activities selected in the questionnaire, on a scale between 0 and 10 . Results are consistent with our findings and are available upon request.
} 
Further, we verify whether the very strong result of Generativity In Act depends from the fact that we grouped Individual and Local Generativity Potential in only one regressor. We therefore repeat our estimates disentangling the two Generativity Potential components. We find that the significance of Generativity in Act (and its magnitude) is unchanged. We also test for the mediating role of expectation including among the regressors individual life expectancy, measured as the probability of being alive in 10 years, and the expectation about a good future, measured in terms of frequency with which individuals think that their future looks good (i.e., never, rarely, sometimes, often). ${ }^{18}$

Finally, we perform a robustness check on the construction of the individual generativity potential. We recompute the index adopting the Mazziotta-Pareto procedure (MPI) (De Muro et al. 2011). The MPI is a composite index that summarizes individual indicators. Starting from arithmetic means of the normalized raw variables, it is based on a nonlinear function that penalizes observations with unbalanced values of the indicators. Results are reported in Tables 21 and 22 for life sense and life satisfaction. Although in this specification the effect of the individual generativity power increases with respect to base specific, we still find individual generativity in act index to be the strongest predictor for life sense, to be more correlated to life sense than to life satisfaction and to work as a buffer when generativity power is scarce. Findings about the trade-off between "freedom of" and "freedom for" remain constant.

\section{Conclusions}

Our work takes inspiration from the well-known concept of generativity, developed by Erikson in social psychology. According to his perspective generativity, intended as the capacity to positively influence one's own community with personal action, is one of the main drivers of life sense and life satisfaction in adult life. If this is the case, we have discovered a source of social and economic choices whose role has been neglected in the construction of standard individual utility functions in economic models.

In the first part of the paper, we introduce for the first time, to our knowledge, this concept in economics, define three dimensions of generativity (personal and local generativity power and personal generativity in act) and relate our work to the subjective well-being and capabilities literature. More specifically, we argue that the concept of personal and local generativity power is akin to that of Amartya Sen's concept of capabilities, while that of personal generativity in act relates to the capacity of transforming the generativity potential into actions that positively affect other human beings.

In order to make testable our general hypothesis on the positive effect of generativity on subjective well-being, we create two variables measuring the third dimension (personal generativity in act) in leisure and work time, respectively.

${ }_{18}$ Results are omitted for reasons of space and available upon request. 
Our findings show that all our generativity variables significantly affect life satisfaction and life sense. In terms of economic significance, the strongest result in magnitude we have is that a unit change from the sample mean of the individual generativity in act component raises by $19.5 \%$ the odds of declaring the highest level of life sense. We also find that individuals with lower personal generativity power enjoy more generativity in act. We finally identify a trade-off between personal generativity in act and internal locus of control since generativity in act implies strong commitment over time use of one's own life and is therefore negatively correlated with control over it. This implies that the gross effect of generativity in act is stronger than the net effect, that is, the impact of personal generativity in act is positive but smaller when we do not correct for the (negative) effect of internal locus of control on subjective well-being. This specific finding implies a trade-off between "freedom for" (personal generativity in act) and "freedom of" (internal locus of control).

Our analysis has limitations that can open several directions for future research. First of all, the trade-off between the opportunity of testing effects of generativity on large existing surveys such as the multi-European (country-level representative) SHARE project and the specific constraints of the survey characteristics imply the limit of a restriction of our analysis to individuals aged 50 and older. While the same Erikson's aging of generativity along the individual life assumes that the concept matters more for the older generations who are inclined to make a balance of their life, an analysis involving also those on the 40 s or even in the 30 s would be important to test the external validity of our findings. Second, the trade-off when using existing surveys is also with the freedom of constructing an ad hoc index of generativity with a richer set of variables created ad hoc by the researcher. In this respect, we as well had to choose for our base scenario restrictive assumptions on the weights of the different generativity index components and, specifically, we have chosen unit weights in our base estimates. In two different robustness checks, we however saw that our findings are robust when using alternative approaches that penalize unbalanced data such as the Mazziota-Pareto index, or use weights based on the correlation between the simple indicators and life satisfaction. In addition to them, other approaches using weights based on sound a priori newly formulated theoretical assumptions related to the importance of each individual component of the composite indicators could be proposed in future research. Another important issue relates to the fact that generativity also implies caring for future generations and therefore an investigation of the nexus between generativity and care for the environment using the indicators and the achievements of our work would be of great interest.

While taking into account these limitations, we believe that our findings have relevant implications for positive and normative economics.

From the first point of view, they identify an unexplored driver of consumption and saving choices and help to shed light on some dilemmas such as the childrenhappiness puzzle showing that individuals decide to have children, even though the 
latter seem to contribute negatively to their own well-being empirically (Frey and Stutzer 2000; Alesina et al. 2004; Di Tella et al. 2003 and Smith 2003). Looking at our findings, this puzzle may be explained by the fact that children positively contribute to generativity in act and to subjective well-being but strongly reduce internal locus of control of parents at their young age. When they grow up the trade-off lessens, thereby contributing positively to parental life satisfaction. If life satisfaction answers are not so forward looking and heavily affected by internal locus of control, this explains the paradox of choosing to have children even though they negatively contribute to the current self-declared life satisfaction.

In terms of policies, our findings indicate that policymakers should set the goal of fully generative societies aiming to maximize the three generativity dimensions for each individual if they want to increase and strengthen political consensus. The toughest and more fascinating challenge is pursuing this goal for individuals that have lower personal generativity potential and, as such, (as shown in our empirical evidence) enjoy more generativity in act. The importance of quality of jobs and policies for active aging (such as lifelong learning to increase capabilities, functionalities and generativity, voluntary work) for the elders and their families is therefore a straightforward consequence of our results.

Funding Open access funding provided by Università degli Studi di Roma Tor Vergata within the CRUICARE Agreement. The paper received no funding

\section{Compliance with ethical standards}

Conflict of interest The authors declare that they have no conflict of interest.

Open Access This article is licensed under a Creative Commons Attribution 4.0 International License, which permits use, sharing, adaptation, distribution and reproduction in any medium or format, as long as you give appropriate credit to the original author(s) and the source, provide a link to the Creative Commons licence, and indicate if changes were made. The images or other third party material in this article are included in the article's Creative Commons licence, unless indicated otherwise in a credit line to the material. If material is not included in the article's Creative Commons licence and your intended use is not permitted by statutory regulation or exceeds the permitted use, you will need to obtain permission directly from the copyright holder. To view a copy of this licence, visit http://creativecommons.org/licen ses/by/4.0/.

\section{Appendix}

See Tables 9, 10, 11, 12, 13, 14, 15, 16, 17, 18, 19, 20, 21 and 22. 


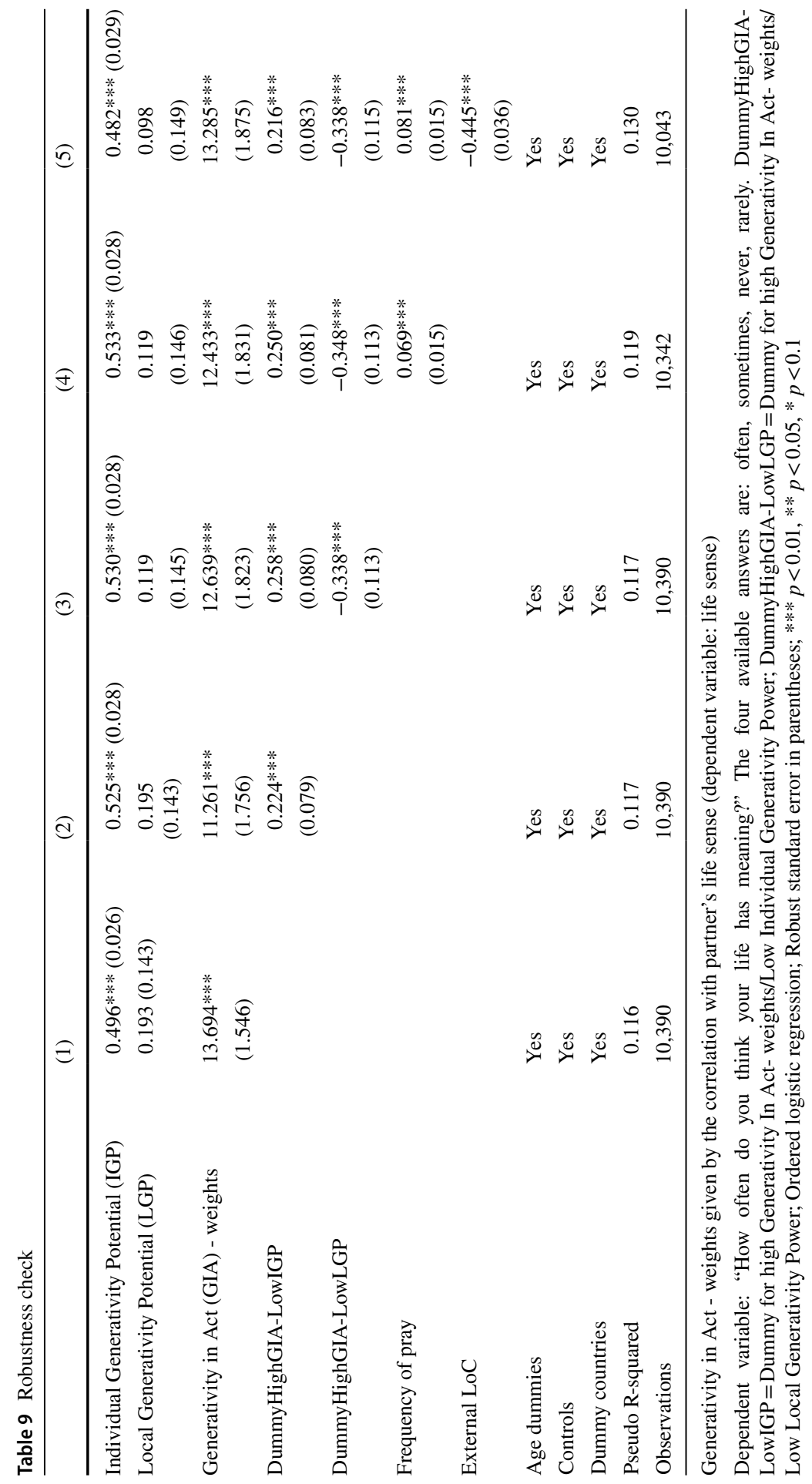


Table 10 Robustness check

\begin{tabular}{|c|c|c|c|c|c|}
\hline & (1) & (2) & (3) & (4) & (5) \\
\hline Individual Generativity Potential (IGP) & $\begin{array}{l}0.593^{* * *} \\
(0.020)\end{array}$ & $\begin{array}{l}0.628 * * * \\
(0.022)\end{array}$ & $\begin{array}{l}0.631 * * * \\
(0.022)\end{array}$ & $\begin{array}{l}0.631 * * * \\
(0.022)\end{array}$ & $\begin{array}{l}0.555^{* * *} \\
(0.023)\end{array}$ \\
\hline Local Generativity Potential (LGP) & $\begin{array}{l}0.531 * * * \\
(0.111)\end{array}$ & $\begin{array}{l}0.531 \text { *** } \\
(0.111)\end{array}$ & $\begin{array}{l}0.498 * * * \\
(0.113)\end{array}$ & $\begin{array}{l}0.499 * * * \\
(0.113)\end{array}$ & $\begin{array}{l}0.484 * * * \\
(0.115)\end{array}$ \\
\hline Generativity in Act (GIA) - weights & $\begin{array}{l}6.093 * * * \\
(0.965)\end{array}$ & $\begin{array}{l}4.547 * * * \\
(1.045)\end{array}$ & $\begin{array}{l}4.919 * * * \\
(1.071)\end{array}$ & $\begin{array}{l}4.820 * * * \\
(1.074)\end{array}$ & $\begin{array}{l}6.288 * * * \\
(1.094)\end{array}$ \\
\hline DummyHighGIA-LowIGP & & $\begin{array}{l}0.233 \text { *** } \\
(0.061)\end{array}$ & $\begin{array}{l}0.247 * * * \\
(0.061)\end{array}$ & $\begin{array}{l}0.242^{* * *} \\
(0.062)\end{array}$ & $\begin{array}{l}0.212 * * * \\
(0.063)\end{array}$ \\
\hline DummyHighGIA-LowLGP & & & $\begin{array}{r}-0.147 \\
(0.092)\end{array}$ & $\begin{array}{r}-0.148 \\
(0.092)\end{array}$ & $\begin{array}{c}-0.168^{*} \\
(0.094)\end{array}$ \\
\hline Frequency of pray & & & & $\begin{array}{l}0.031 * * * \\
(0.011)\end{array}$ & $\begin{array}{l}0.048 * * * \\
(0.011)\end{array}$ \\
\hline External LoC & & & & & $\begin{array}{c}-0.700^{* * *} \\
(0.029)\end{array}$ \\
\hline Age dummies & Yes & Yes & Yes & Yes & Yes \\
\hline Controls & Yes & Yes & Yes & Yes & Yes \\
\hline Dummy countries & Yes & Yes & Yes & Yes & Yes \\
\hline Pseudo R-squared & 0.0786 & 0.0790 & 0.0791 & 0.0794 & 0.0955 \\
\hline Observations & 10,440 & 10,440 & 10,440 & 10,389 & 10,052 \\
\hline
\end{tabular}

Generativity in Act - weights given by the correlation with partner's life satisfaction (dependent variable: life satisfaction)

Dependent variable: "Are you satisfied with your life?" Answers can range from 0 (completely unsatisfied) to 10 (fully satisfied). DummyHighGIA-LowIGP = Dummy for high Generativity In Act- weights/ Low Individual Generativity Power; DummyHighGIA-LowLGP = Dummy for high Generativity In Actweights/Low Local Generativity Power; Ordered logistic regression; Robust standard errors in parentheses; *** $p<0.01, * * p<0.05, * p<0.1$ 
Table 11 Robustness check

\begin{tabular}{|c|c|c|c|c|c|}
\hline & (1) & (2) & (3) & (4) & (5) \\
\hline Individual Generativity Potential (IGP) & $\begin{array}{l}0.503 * * * \\
(0.026)\end{array}$ & $\begin{array}{l}0.530 * * * \\
(0.028)\end{array}$ & $\begin{array}{l}0.534 * * * \\
(0.028)\end{array}$ & $\begin{array}{l}0.537 * * * \\
(0.028)\end{array}$ & $\begin{array}{l}0.487 * * * \\
(0.030)\end{array}$ \\
\hline Local Generativity Potential (LGP) & $\begin{array}{c}0.196 \\
(0.143)\end{array}$ & $\begin{array}{c}0.193 \\
(0.143)\end{array}$ & $\begin{array}{c}0.137 \\
(0.146)\end{array}$ & $\begin{array}{c}0.136 \\
(0.146)\end{array}$ & $\begin{array}{c}0.116 \\
(0.149)\end{array}$ \\
\hline Generativity in Act (GIA) - frequency & $\begin{array}{l}0.426 * * * \\
(0.051)\end{array}$ & $\begin{array}{l}0.364 * * * \\
(0.057)\end{array}$ & $\begin{array}{l}0.392 * * * \\
(0.059)\end{array}$ & $\begin{array}{l}0.383 * * * \\
(0.059)\end{array}$ & $\begin{array}{l}0.407 * * * \\
(0.060)\end{array}$ \\
\hline DummyHighGIA-LowIGP & & $\begin{array}{l}0.170 * * \\
(0.073)\end{array}$ & $\begin{array}{l}0.195^{* * *} \\
(0.074)\end{array}$ & $\begin{array}{l}0.191 * * * \\
(0.074)\end{array}$ & $\begin{array}{l}0.165^{* *} \\
(0.076)\end{array}$ \\
\hline DummyHighGIA-LowLGP & & & $\begin{array}{c}-0.215^{* *} \\
(0.106)\end{array}$ & $\begin{array}{c}-0.228^{* *} \\
(0.106)\end{array}$ & $\begin{array}{c}-0.211^{*} \\
(0.108)\end{array}$ \\
\hline Frequency of pray & & & & $\begin{array}{l}0.067 * * * \\
(0.015)\end{array}$ & $\begin{array}{l}0.080 * * * \\
(0.015)\end{array}$ \\
\hline External LoC & & & & & $\begin{array}{c}-0.448^{* * *} \\
(0.036)\end{array}$ \\
\hline Age dummies & Yes & Yes & Yes & Yes & Yes \\
\hline Controls & Yes & Yes & Yes & Yes & Yes \\
\hline Dummy countries & Yes & Yes & Yes & Yes & Yes \\
\hline Pseudo R-squared & 0.116 & 0.116 & 0.116 & 0.118 & 0.129 \\
\hline Observations & 10,390 & 10,390 & 10,390 & 10,342 & 10,043 \\
\hline
\end{tabular}

Generativity in Act with activities frequency (dependent variable: life sense)

Dependent variable: "How often do you think your life has meaning?" The four available answers are: often, sometimes, never, rarely. DummyHighGIA-LowIGP=Dummy for high Generativity In Act- frequency/Low Individual Generativity Power; DummyHighGIA-LowLGP = Dummy for high Generativity In Act- frequency/Low Local Generativity Power; Ordered logistic regression; Robust standard errors in parentheses; *** $p<0.01$, ** $p<0.05, * p<0.1$ 
Table 12 Robustness check

\begin{tabular}{|c|c|c|c|c|c|}
\hline & (1) & (2) & (3) & (4) & (5) \\
\hline Individual Generativity Potential (IGP) & $\begin{array}{l}0.598 * * * \\
(0.020)\end{array}$ & $\begin{array}{l}0.621 * * * \\
(0.022)\end{array}$ & $\begin{array}{l}0.623 * * * \\
(0.022)\end{array}$ & $\begin{array}{l}0.624 * * * \\
(0.022)\end{array}$ & $\begin{array}{l}0.547 * * * \\
(0.023)\end{array}$ \\
\hline Local Generativity Potential (LGP) & $\begin{array}{l}0.536 * * * \\
(0.111)\end{array}$ & $\begin{array}{l}0.533 \text { *** } \\
(0.111)\end{array}$ & $\begin{array}{l}0.511 * * * \\
(0.113)\end{array}$ & $\begin{array}{l}0.509 \text { *** } \\
(0.113)\end{array}$ & $\begin{array}{l}0.494 * * * \\
(0.115)\end{array}$ \\
\hline Generativity in Act (GIA) - frequency & $\begin{array}{l}0.196^{* * *} \\
(0.033)\end{array}$ & $\begin{array}{l}0.165^{* * *} \\
(0.035)\end{array}$ & $\begin{array}{l}0.172 * * * \\
(0.036)\end{array}$ & $\begin{array}{l}0.170 * * * \\
(0.036)\end{array}$ & $\begin{array}{l}0.223 * * * \\
(0.037)\end{array}$ \\
\hline DummyHighGIA-LowIGP & & $\begin{array}{l}0.143 * * \\
(0.057)\end{array}$ & $\begin{array}{l}0.154 * * * \\
(0.058)\end{array}$ & $\begin{array}{l}0.153 * * * \\
(0.058)\end{array}$ & $\begin{array}{l}0.120 * * \\
(0.060)\end{array}$ \\
\hline DummyHighGIA-LowLGP & & & $\begin{array}{c}-0.097 \\
(0.088)\end{array}$ & $\begin{array}{r}-0.107 \\
(0.088)\end{array}$ & $\begin{array}{r}-0.127 \\
(0.090)\end{array}$ \\
\hline Frequency of pray & & & & $\begin{array}{l}0.031 * * * \\
(0.011)\end{array}$ & $\begin{array}{l}0.048 * * * \\
(0.011)\end{array}$ \\
\hline External LoC & & & & & $\begin{array}{c}-0.703^{* * *} \\
(0.029)\end{array}$ \\
\hline Age dummies & Yes & Yes & Yes & Yes & Yes \\
\hline Controls & Yes & Yes & Yes & Yes & Yes \\
\hline Dummy countries & Yes & Yes & Yes & Yes & Yes \\
\hline Pseudo R-squared & 0.0785 & 0.0787 & 0.0787 & 0.0791 & 0.0952 \\
\hline Observations & 10,440 & 10,440 & 10,440 & 10,389 & 10,052 \\
\hline
\end{tabular}

Generativity in Act with activities frequency (dependent variable: life satisfaction)

Dependent variable: "Are you satisfied with your life?" Answers can range from 0 (completely unsatisfied) to 10 (fully satisfied). DummyHighGIA-LowIGP Dummy for high Generativity In Act- frequency/ Low Individual Generativity Power; DummyHighGIA-LowLGP= Dummy for high Generativity In Actfrequency/Low Local Generativity Power; Ordered logistic regression; Robust standard errors in parentheses; *** $p<0.01, * * p<0.05, * p<0.1$ 


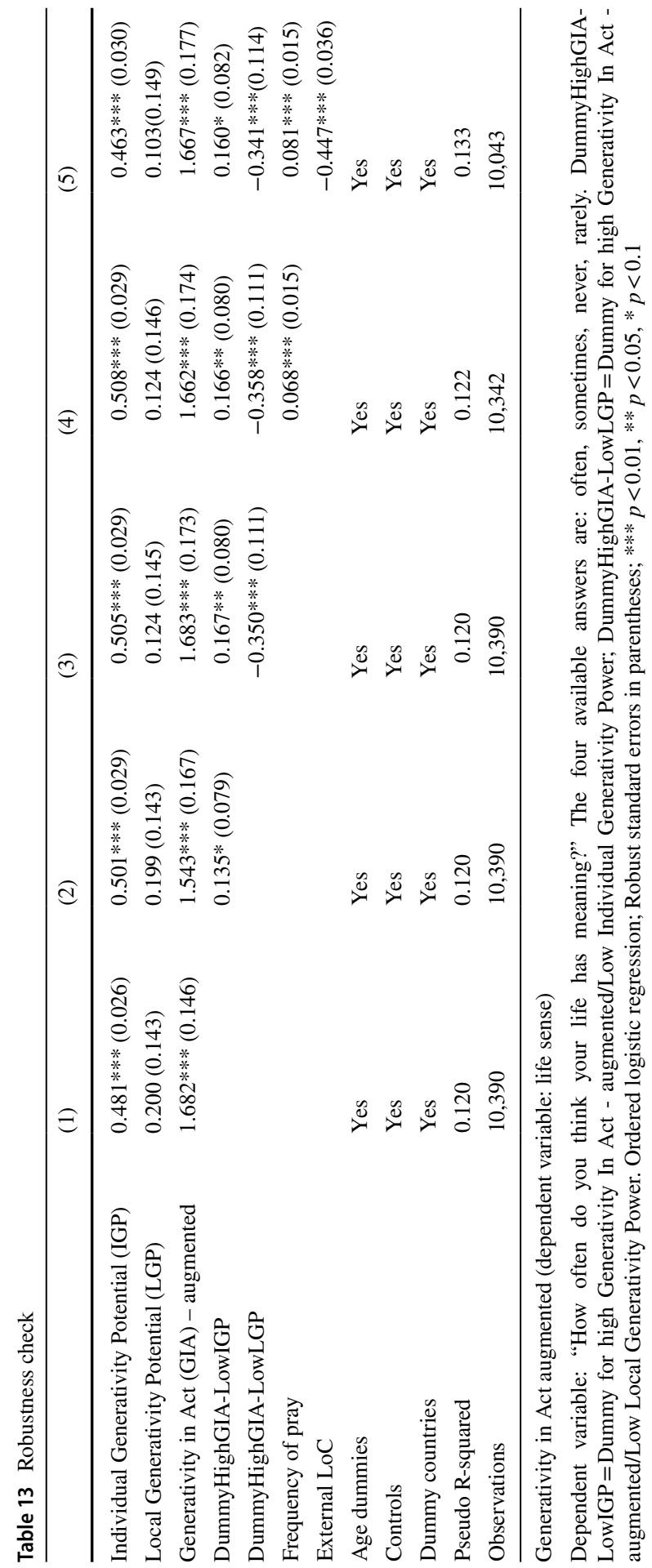


Table 14 Robustness check

\begin{tabular}{|c|c|c|c|c|c|}
\hline & (1) & (2) & (3) & (4) & (5) \\
\hline Individual Generativity Potential (IGP) & $\begin{array}{l}0.588 * * * \\
(0.020)\end{array}$ & $\begin{array}{l}0.614 * * * \\
(0.022)\end{array}$ & $\begin{array}{l}0.614 * * * \\
(0.022)\end{array}$ & $\begin{array}{l}0.615 * * * \\
(0.022)\end{array}$ & $\begin{array}{l}0.536 * * * \\
(0.023)\end{array}$ \\
\hline Local Generativity Potential (LGP) & $\begin{array}{l}0.537 * * * \\
(0.111)\end{array}$ & $\begin{array}{l}0.534 * * * \\
(0.111)\end{array}$ & $\begin{array}{l}0.522 * * * \\
(0.112)\end{array}$ & $\begin{array}{l}0.523 \text { *** } \\
(0.113)\end{array}$ & $\begin{array}{l}0.515^{* * *} \\
(0.115)\end{array}$ \\
\hline Generativity in Act (GIA) - augmented & $\begin{array}{l}0.742 * * * \\
(0.102)\end{array}$ & $\begin{array}{l}0.632 * * * \\
(0.111)\end{array}$ & $\begin{array}{l}0.646^{* * *} \\
(0.114)\end{array}$ & $\begin{array}{l}0.641 * * * \\
(0.114)\end{array}$ & $\begin{array}{l}0.809 * * * \\
(0.116)\end{array}$ \\
\hline DummyHighGIA-LowIGP & & $\begin{array}{l}0.156^{* * *} \\
(0.061)\end{array}$ & $\begin{array}{l}0.161 * * * \\
(0.061)\end{array}$ & $\begin{array}{l}0.164 * * * \\
(0.061)\end{array}$ & $\begin{array}{l}0.125 * * \\
(0.063)\end{array}$ \\
\hline DummyHighGIA-LowLGP & & & $\begin{array}{c}-0.054 \\
(0.091)\end{array}$ & $\begin{array}{c}-0.057 \\
(0.091)\end{array}$ & $\begin{array}{r}-0.045 \\
(0.093)\end{array}$ \\
\hline Frequency of pray & & & & $\begin{array}{l}0.031 * * * \\
(0.011)\end{array}$ & $\begin{array}{l}0.048 * * * \\
(0.011)\end{array}$ \\
\hline External LoC & & & & & $\begin{array}{c}-0.705^{* * *} \\
(0.029)\end{array}$ \\
\hline Age dummies & Yes & Yes & Yes & Yes & Yes \\
\hline Controls & Yes & Yes & Yes & Yes & Yes \\
\hline Dummy countries & Yes & Yes & Yes & Yes & Yes \\
\hline Pseudo R-squared & 0.0790 & 0.0791 & 0.0791 & 0.0795 & 0.0958 \\
\hline Observations & 10,440 & 10,440 & 10,440 & 10,389 & 10,052 \\
\hline
\end{tabular}

Generativity in Act augmented (dependent variable: life satisfaction)

Dependent variable: "Are you satisfied with your life?" Answers can range from 0 (completely unsatisfied) to 10 (fully satisfied). DummyHighGIA-LowIGP = Dummy for high Generativity In Act- augmented/Low Individual Generativity Power; DummyHighGIA-LowLGP = Dummy for high Generativity In Act- augmented/Low Local Generativity Power; Ordered logistic regression; Robust standard errors in parentheses; *** $p<0.01,{ }^{*} * p<0.05, * p<0.1$ 


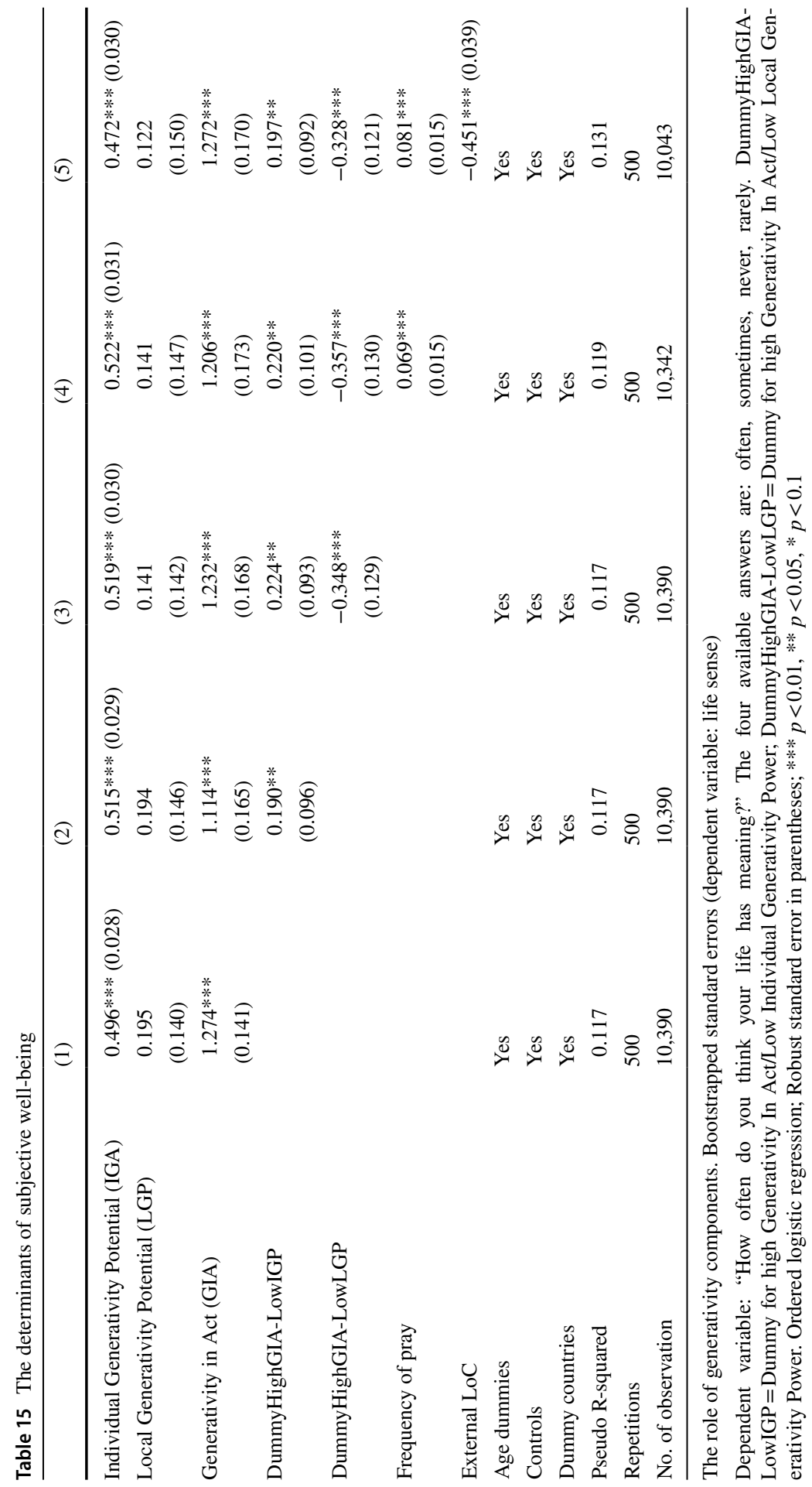


Table 16 The determinants of subjective well-being

\begin{tabular}{|c|c|c|c|c|c|}
\hline & (1) & (2) & (3) & (4) & (5) \\
\hline Individual Generativity Potential (IGP) & $\begin{array}{l}0.595 * * * \\
(0.020)\end{array}$ & $\begin{array}{l}0.627 * * * \\
(0.023)\end{array}$ & $\begin{array}{l}0.628 * * * \\
(0.022)\end{array}$ & $\begin{array}{l}0.629 * * * \\
(0.023)\end{array}$ & $\begin{array}{l}0.551 * * * \\
(0.024)\end{array}$ \\
\hline Local Generativity Potential (LGP) & $\begin{array}{l}0.533 * * * \\
(0.117)\end{array}$ & $\begin{array}{l}0.532 \text { *** } \\
(0.116)\end{array}$ & $\begin{array}{l}0.521 * * * \\
(0.112)\end{array}$ & $\begin{array}{l}0.523^{* * *} \\
(0.114)\end{array}$ & $\begin{array}{l}0.518 \text { *** } \\
(0.118)\end{array}$ \\
\hline Generativity in Act (GIA) & $\begin{array}{l}0.569 * * * \\
(0.092)\end{array}$ & $\begin{array}{l}0.405^{* * *} * \\
(0.099)\end{array}$ & $\begin{array}{l}0.421 * * * \\
(0.105)\end{array}$ & $\begin{array}{l}0.411 * * * \\
(0.104)\end{array}$ & $\begin{array}{l}0.591 * * * \\
(0.096)\end{array}$ \\
\hline DummyHighGIA-LowIGP & & $\begin{array}{l}0.285^{* * *} \\
(0.071)\end{array}$ & $\begin{array}{l}0.291 * * * \\
(0.072)\end{array}$ & $\begin{array}{l}0.294 * * * \\
(0.074)\end{array}$ & $\begin{array}{l}0.255^{* * *} \\
(0.072)\end{array}$ \\
\hline DummyHighGIA-LowLGP & & & $\begin{array}{r}-0.073 \\
(0.110)\end{array}$ & $\begin{array}{r}-0.072 \\
(0.101)\end{array}$ & $\begin{array}{r}-0.048 \\
(0.107)\end{array}$ \\
\hline Frequency of pray & & & & $\begin{array}{l}0.031 * * * \\
(0.011)\end{array}$ & $\begin{array}{l}0.048 * * * \\
(0.011)\end{array}$ \\
\hline External LoC & & & & & $\begin{array}{c}-0.705^{* * *} \\
(0.031)\end{array}$ \\
\hline Age dummies & Yes & Yes & Yes & Yes & Yes \\
\hline Controls & Yes & Yes & Yes & Yes & Yes \\
\hline Dummy countries & Yes & Yes & Yes & Yes & Yes \\
\hline Repetitions & 500 & 500 & 500 & 500 & 500 \\
\hline Pseudo R-squared & 0.079 & 0.079 & 0.079 & 0.079 & 0.096 \\
\hline No. of observation & 10,440 & 10,440 & 10,440 & 10,389 & 10,052 \\
\hline
\end{tabular}

The role of generativity components. Bootstrapped standard errors (dependent variable: life satisfaction) Dependent variable: "Are you satisfied with your life?" Answers can range from 0 (completely unsatisfied) to 10 (fully satisfied). DummyHighGIA-LowIGP=Dummy for high Generativity In Act/Low Individual Generativity Power; DummyHighGIA-LowLGP = Dummy for high Generativity In Act/Low Local Generativity Power; Ordered logistic regression; Bootstrap standard error in parentheses, 500 repetition; *** $p<0.01$, ** $p<0.05, * p<0.1$

Table 17 Sensitivity analysis

\begin{tabular}{llr}
\hline Omitted country & $\begin{array}{l}\text { Generativity in Act coef- } \\
\text { ficients }\end{array}$ & DFBETA \\
\hline Germany & $1.137 * * *$ & 0.681 \\
Sweden & $1.151 * * *$ & 0.663 \\
Netherlands & $1.368 * * *$ & -0.538 \\
Spain & $1.284 * * *$ & -0.070 \\
Italy & $1.206 * * *$ & 0.376 \\
France & $1.236 * * *$ & 0.215 \\
Denmark & $1.319 * * *$ & -0.262 \\
Belgium & $1.393 * * *$ & -0.671 \\
Czech Republic & $1.287 * * *$ & -0.084 \\
\hline
\end{tabular}

DFBETA omitting country (dependent variable: life sense) 
Table 18 Sensitivity analysis

Table 19 Sensitivity analysis

Table 20 Sensitivity analysis
Omitted Country

Generativity in Act coefficients

\begin{tabular}{llr}
\hline Germany & $0.328 * *$ & 2.030 \\
Sweden & $0.570 * * *$ & 0.183 \\
Netherlands & $0.600 * * *$ & -0.072 \\
Spain & $0.594 * * *$ & -0.022 \\
Italy & $0.629 * * *$ & -0.343 \\
France & $0.596 * * *$ & -0.041 \\
Denmark & $0.680 * * *$ & -0.765 \\
Belgium & $0.607 * * *$ & -0.145 \\
Czech Republic & $0.659 * * *$ & -0.610 \\
\hline
\end{tabular}

DFBETA omitting country (dependent variable: life satisfaction)

\begin{tabular}{llr}
\hline Gender & $\begin{array}{l}\text { Generativity in Act coef- } \\
\text { ficients }\end{array}$ & DFBETA \\
\hline Full sample & $1.267 * * *$ & \\
Only male & $1.504 * * *$ & -0.971 \\
Only female & $1.055^{* * *}$ & 0.905
\end{tabular}

DFBETA omitting gender (dependent variable: life sense)

\begin{tabular}{llr}
\hline Gender & $\begin{array}{l}\text { Generativity in Act coef- } \\
\text { ficients }\end{array}$ & DFBETA \\
\hline Full sample & $0.584^{* * *}$ & \\
Only male & $0.936^{* * *}$ & -2.236 \\
Only female & $0.332^{* *}$ & 1.720 \\
\hline
\end{tabular}

DFBETA omitting gender (dependent variable: life satisfaction) 
Table 21 Robustness check

\begin{tabular}{lccccc}
\hline & $(1)$ & $(2)$ & $(3)$ & $(4)$ & $(5)$ \\
\hline Individual Generativity Potential (IGP) & $0.982^{* * *}$ & $1.017^{* * *}$ & $1.026^{* * *}$ & $1.032^{* * * *}$ & $0.930^{* * * *}$ \\
$\quad$ - MPI & $(0.059)$ & $(0.062)$ & $(0.062)$ & $(0.063)$ & $(0.065)$ \\
Local Generativity Potential (LGP) & 0.186 & 0.188 & 0.135 & 0.136 & 0.108 \\
& $(0.142)$ & $(0.143)$ & $(0.144)$ & $(0.144)$ & $(0.148)$ \\
Generativity in Act (GIA) & $1.308^{* * *}$ & $1.173^{* * *}$ & $1.287^{* * *}$ & $1.258^{* * *}$ & $1.314^{* * *}$ \\
& $(0.138)$ & $(0.159)$ & $(0.165)$ & $(0.165)$ & $(0.169)$ \\
DummyHighGIA-LowIGP - MPI & & $0.152^{*}$ & $0.190^{* *}$ & $0.189^{* * *}$ & $0.174^{*}$ \\
& & $(0.090)$ & $(0.092)$ & $(0.092)$ & $(0.094)$ \\
DummyHighGIA-LowLGP & & & $-0.350^{* * *}$ & $-0.360^{* * *}$ & $-0.333^{* * *}$ \\
& & & $(0.125)$ & $(0.125)$ & $(0.128)$ \\
Frequency of pray & & & & $0.070^{* * *}$ & $0.082^{* * *}$ \\
& & & & $(0.015)$ & $(0.015)$ \\
External LoC & & & & & $-0.482^{* * *}$ \\
& & & & & $(0.036)$ \\
Observations & 10,327 & 10,327 & 10,327 & 10,279 & 9989 \\
Age dummies & Yes & Yes & Yes & Yes & Yes \\
Controls & Yes & Yes & Yes & Yes & Yes \\
Dummy countries & Yes & Yes & Yes & Yes & Yes \\
Pseudo R-squared & 0.111 & 0.111 & 0.111 & 0.113 & 0.126 \\
Observations & 10,327 & 10,327 & 10,327 & 10,279 & 9989 \\
\hline
\end{tabular}

Individual Generativity Power MPI (dependent variable: life sense) 
Table 22 Robustness check

(1)

(2)

(3)

(4)

(5)

\begin{tabular}{|c|c|c|c|c|c|}
\hline $\begin{array}{l}\text { Individual Generativity Potential (IGP) - } \\
\text { MPI }\end{array}$ & $\begin{array}{l}1.155^{* * *} \\
(0.045)\end{array}$ & $\begin{array}{l}1.214 * * * \\
(0.048)\end{array}$ & $\begin{array}{l}1.216^{* * * *} \\
(0.048)\end{array}$ & $\begin{array}{l}1.219 * * * \\
(0.048)\end{array}$ & $\begin{array}{l}1.066^{* * * *} \\
(0.050)\end{array}$ \\
\hline Local Generativity Potential (LGP) & $\begin{array}{l}0.499 * * * \\
(0.111)\end{array}$ & $\begin{array}{l}0.503 * * * \\
(0.111)\end{array}$ & $\begin{array}{l}0.492 * * * \\
(0.112)\end{array}$ & $\begin{array}{l}0.497 * * * \\
(0.112)\end{array}$ & $\begin{array}{l}0.489 * * * \\
(0.114)\end{array}$ \\
\hline Generativity in Act (GIA) & $\begin{array}{l}0.628 * * * \\
(0.094)\end{array}$ & $\begin{array}{l}0.489 * * * \\
(0.103)\end{array}$ & $\begin{array}{l}0.504 * * * \\
(0.105)\end{array}$ & $\begin{array}{l}0.491 * * * \\
(0.106)\end{array}$ & $\begin{array}{l}0.669 * * * \\
(0.108)\end{array}$ \\
\hline DummyHighGIA-LowIGP & & $\begin{array}{l}0.221 * * * \\
(0.067)\end{array}$ & $\begin{array}{l}0.227 * * * \\
(0.068)\end{array}$ & $\begin{array}{l}0.232 * * * \\
(0.068)\end{array}$ & $\begin{array}{l}0.193 * * * \\
(0.069)\end{array}$ \\
\hline DummyHighGIA-LowLGP & & & $\begin{array}{r}-0.066 \\
(0.101)\end{array}$ & $\begin{array}{r}-0.064 \\
(0.101)\end{array}$ & $\begin{array}{r}-0.038 \\
(0.103)\end{array}$ \\
\hline Frequency of pray & & & & $\begin{array}{l}0.030 * * * \\
(0.011)\end{array}$ & $\begin{array}{l}0.047 * * * \\
(0.011)\end{array}$ \\
\hline External LoC & & & & & $\begin{array}{l}-0.741 * * * \\
(0.029)\end{array}$ \\
\hline Observations & 10,376 & 10,376 & 10,376 & 10,326 & 9997 \\
\hline Age dummies & Yes & Yes & Yes & Yes & Yes \\
\hline Controls & Yes & Yes & Yes & Yes & Yes \\
\hline Dummy countries & Yes & Yes & Yes & Yes & Yes \\
\hline Pseudo $R$-squared & 0.0726 & 0.0728 & 0.0729 & 0.0732 & 0.0912 \\
\hline Observations & 10,376 & 10,376 & 10,376 & 10,326 & 9997 \\
\hline
\end{tabular}

Individual Generativity Power MPI (dependent variable: life satisfaction)

\section{References}

Alesina A, Di Tella R, MacCulloch R (2004) Inequality and happiness: are Europeans and Americans different? J Public Econ 88:2009-2042

Appels A, Bosma H, Grabauskas V, Gostautas A, Sturmans F (1996) Self-rated health and mortality in a Lithuanian and a Dutch population. Soc Sci Med 42:681-689

Becchetti L, Pelloni A (2013) What are we learning from the life satisfaction literature? Int Rev Econ 60(2):113-155

Becchetti L, Becchetti M, Pisani F (2019) Poor eudaimonic subjective wellbeing as a mortality risk factor. Economia Politica 36(1):245-272

Belsley DA, Kuh E, Welsch RE (1980) Regression diagnostics: identifying influential data and sources of collinearity. Wiley, Hoboken

Benjamins MR, Hummer RA, Eberstein IW, Nam CB (2004) Self-reported health and adult mortality risk: an analysis of cause-specific mortality. Soc Sci Med 59:1297-1306

Blanchflower DG, Oswald AJ (2004) Well-being over time in Britain and the US. J Public Econ 88(7-8):1359-1386

Clark A (2008) Happiness, habits and high rank: comparisons in economic and social life. PSE, Discussion Paper No. 2008-61

Clark A, Senik C (2010) Who compares to Whom? the anatomy of income comparisons in Europe. Econ J 120:573-594

Clark A, Frijters P, Shields MA (2006) Income and happiness: evidence, explanations and economic implications. Paris Jourdan Sciences Economiques, working paper 2006-24

Davidshofer KR, Murphy CO (2005) Psychological testing: principles and applications. Upper Saddle River, Pearson Prentice Hall 
Fisher BJ (1995) Successful aging, life satisfaction, and generativity in later life. Int J Aging Human Dev 41(3):239-250

Hofer J, Busch H, Au A., Šolcová IP, Tavel P, Wong TT (2016) Generativity does not necessarily satisfy all your needs: Associations among cultural demand for generativity, generative concern, generative action, and need satisfaction in the elderly in four cultures. Dev Psychol 52:509-519

Jia F, Alisat S, Soucie K, Pratt M (2015) Generative concern and environmentalism. Emerg Adulthood 3:306-319

Jia F, Soucie K, Alisat S, Pratt M (2016) Sowing seeds for future generations. Int J Behav Dev 40:466-470

Matsuba MK, Pratt MW, Norris JE, Mohle E, Alisat S, McAdams DP (2012) Environmentalism as a context for expressing identity and generativity: patterns among activists and uninvolved youth and midlife adults. J Personal 80(4):1091-1115

De Muro P, Mazziotta M, Pareto A (2011) Composite indices of development and poverty: an application to MDGs. Social Indicator Res 104:1-18

Di Tella R, MacCulloch R, Oswald A (2003) The macroeconomics of happiness. Rev Econ Stat 85:809-827

Dorn D, Fischer J, Kirchgässner G, Sousa-Poza A (2008) Direct democracy and life satisfaction revisited: new evidence for Switzerland. J Happiness Stud 9:227-255

Easterlin RA, Angelescu L (2009) Happiness and growth the world over: time series evidence on the happiness-income paradox. IZA Discussion Paper, (4060)

Erikson EH (1993) Childhood and society, 2nd edn. Norton, New York

Erikson EH, Erikson JM (1998) The life cycle completed. Norton, New York

Ferrer-i-Carbonell A (2005) Income and well-being: an empirical analysis of the comparison income effect. J Public Econ 89(5-6):997-1019

Frey BS, Stutzer A (2000) Happiness, economy and institutions. Econ J 110:918-938

Frey B, Stutzer A (2002) What can economists learn from happiness research. J Econ Lit 40:402-435

Frey B, Luechinger S, Stutzer A (2009) The life satisfaction approach to the value of public goods: the case of terrorism. Public Choice 138:317-345

Idler EL, Angel RJ (1990) Self-rated health and mortality in the NHANES-I epidemiologic follow-up study. Am J Public Health 80:446-452

Idler EL, Kasl SV (1995) Self-ratings of health: do they also predict change in functional ability? J Gerontol Ser B 50(6):S344-S353

Judge TA (1992) Job satisfaction and subjective well-being as determinants of job adaption. In: Academy of management proceedings, vol. 1992, no. 1, pp 222-226

Judge TA, Thoresen CJ, Bono JE, Patton GK (2001) The job satisfaction-job performance relationship: a qualitative and quantitative review. Psychol Bull 127(3):376

Kahneman D, Fredrickson BL (1993) Duration neglect in retrospective evaluations of affective episodes. J Pers Soc Psychol 65:44-55

Luechinger S (2009) Valuing air quality using the life satisfaction approach. Econ J 119(536):482-515

Luechinger S, Raschky PA (2009) Valuing flood disasters using the life satisfaction approach. J Public Econ 93(3-4):620-633

McAdams DP, de St Aubin ED (1992) A theory of generativity and its assessment through self-report, behavioral acts, and narrative themes in autobiography. J Pers Soc Psychol 62(6):1003

McAdams D, St. Aubin E (1998) Generativity and adult development: how and why we care for the next generation, 7th edn. American psychological association, Massachusetts

McCallum J, Shadbolt B, Wang D (1994) Self-rated health and survival: a 7-year follow-up study of Australian elderly". Am J Public Health 847:1100-1105

Mo PH (2001) Corruption and economic growth. J Comparative Econ 29(1):66-79

Nardo M, Saisana M, Saltelli A, Tarantola S (2005) Tools for composite indicators building. Joint Research Centre-European Commission, Ispra (Italy)

Nikolaev B (2018) Does higher education increase hedonic and eudaimonic happiness? J Happiness Stud 19(2):483-504

Nussbaum M (1988) Nature, function, and capability: aristotle on political distribution. In: Oxford studies in ancient philosophy. Oxford University Press, Oxford

Otterbach S (2010) Mismatches between actual and preferred work time: empirical evidence of hours constraints in 21 countries. J Consum Policy 33(2):143-161

Redelmeier DA, Kahneman D (1996) Patients' memories of painful medical treatments: real-time and retrospective evaluations of two minimally invasive procedures. Pain 1996(66):3-8 
Rotter J (1966) Generalized expectancies for internal versus external control of reinforcement. Psychol Monogr 80:1

Schwarz N, Clore GL (1983) Mood, misattribution, and judgments of well-being: informative and directive functions of affective states. J Pers Soc Psychol 45:513-523

Sen AK (1985) Commodities and Capabilities. North-Holland, Amsterdam

Shahen ME, Shahrier S, Kotani K (2019) Happiness, generativity and social value orientation in a developing country. Sustainability 11:5256

Smith K (2003) Individual welfare in the Soviet Union. Soc Indic Res 64:75-105

St. Aubin E, McAdams D, Kim T (2004) The generative society: caring for future generations. American Psychological Association, Massachusetts

Staw BM, Barsade SG (1993) Affect and managerial performance: a test of the sadder-but-wiser vs. happier-and-smarter hypotheses. Adm Sci Quart 38:304-331

Stevenson B, Wolfers J (2008) Economic growth and subjective well-being: reassessing the Easterlin Paradox, CEPR Discussion Papers 6944

Van Praag BMS, Baarsma BE (2005) Using happiness surveys to value intangibles: the case of airport noise. Econ J 115(2005):224-246

Veenhoven R (1993) Happiness in nations: subjective appreciation of life in 56 nations 1946-1992. RISBO-Erasmus University Rotterdam, Rotterdam

Welsch H (2002) Preferences over prosperity and pollution: environmental valuation based on happiness surveys. Kyklos 55:473-494

Publisher's Note Springer Nature remains neutral with regard to jurisdictional claims in published maps and institutional affiliations. 